Issued by Sandia National Laboratories, operated for the United States Department of Energy by Sandia Corporation.

NOTICE: This report was prepared as an account of work sponsored by an agency of the United States Government. Neither the United States Government, nor any agency thereof, nor any of their employees, nor any of their contractors, subcontractors, or their employees, make any warranty, express or implied, or assume any legal liability or responsibility for the accuracy, completeness, or usefulness of any information, apparatus, product, or process disclosed, or represent that its use would not infringe privately owned rights. Reference herein to any specific commercial product, process, or service by trade name, trademark, manufacturer, or otherwise, does not necessarily constitute or imply its endorsement, recommendation, or favoring by the United States Government, any agency thereof, or any of their contractors or subcontractors. The views and opinions expressed herein do not necessarily state or reflect those of the United States Government, any agency thereof, or any of their contractors.

Printed in the United States of America. This report has been reproduced directly from the best available copy.

Available to DOE and DOE contractors from

Office of Scientific and Technical Information

P.O. Box 62

Oak Ridge, TN 37831

Prices available from (703) 605-6000

Web site: http://www.ntis.gov/ordering.htm

Available to the public from

National Technical Information Service

U.S. Department of Commerce

5285 Port Royal Rd

Springfield, VA 22161

NTIS price codes

Printed copy: A03

Microfiche copy: A01

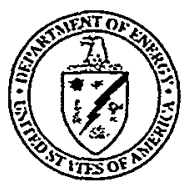




\section{DISCLAIMER}

Portions of this document may be illegible in electronic image products. Images are produced from the best available original document. 
SAND99-2166

Unlimited Release

Printed September 1999

\title{
Corrosion of Uranium in Desert Soil, with Application to GCD Source Term Models
}

\author{
James L. Krumhansl, Mollie E. Thompson, Harlan W. Stockman, Howard L. Anderson and \\ Julianne Baca \\ Geochemistry Department \\ Sandia National Laboratories \\ P.O. Box 5800 \\ Albuquerque, NM 87185-0750
}

\begin{abstract}
Uranium fragments from the Sandia Sled Track were studied as analogues for weapons components and depleted uranium buried at the Greater Confinement Disposal (GCD) site in Nevada. The Sled Track uranium fragments originated as weapons mockups and counterweights impacted on concrete and soil barriers, and experienced heating and fragmentation similar to processes thought to affect the Nuclear Weapons Accident Residues (NWAR) at GCD. Furthermore, the Sandia uranium was buried in unsaturated desert soils for 10 to 40 years, and has undergone weathering processes expected to affect the GCD wastes. Scanning electron microscopy, X-ray diffraction and microprobe analyses of the fragments show rapid alteration from metals to dominantly VI-valent oxy-hydroxides. Leaching studies of the samples give results consistent with published U-oxide dissolution rates, and suggest longer experimental periods (ca. 1 year) would be required to reach equilibrium solution concentrations. Thermochemical modeling with the EQ3/6 code indicates that the uranium concentrations in solutions saturated with becquerelite could increase as the pore waters evaporate, due to changes in carbonate equilibria and increased ionic strength.
\end{abstract}




\section{TABLE OF CONTENTS}

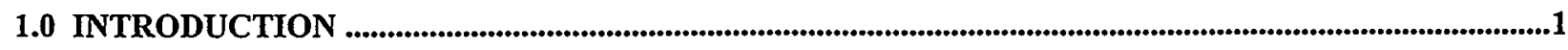

2.0 BACKGROUND

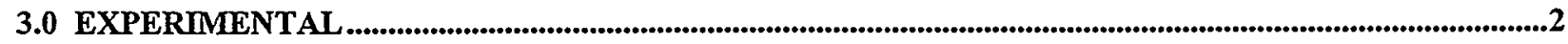

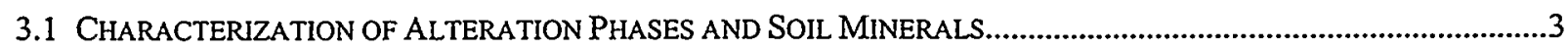

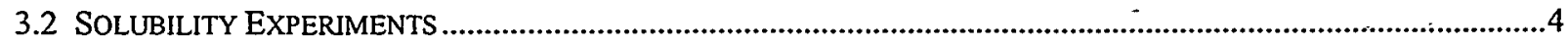

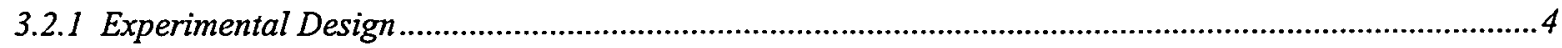

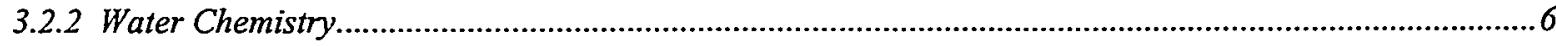

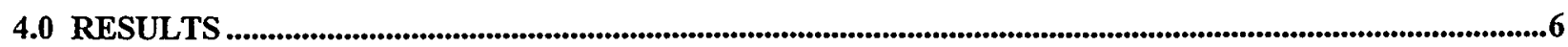

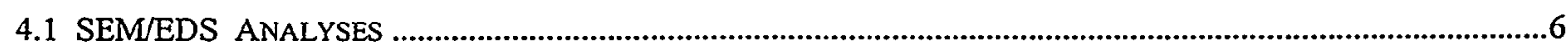

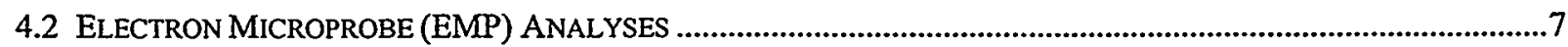

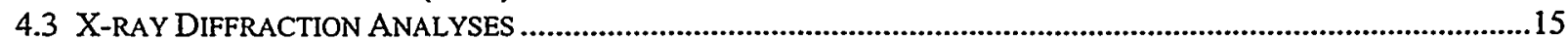

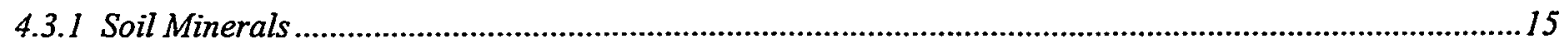

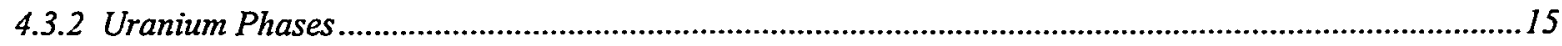

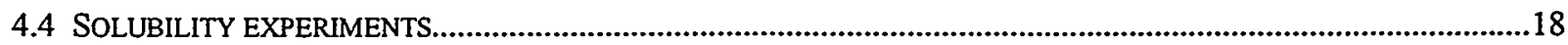

4.4.1 Experiment 1- Soil/Water........................................................................................................................18

4.4.2 Experiments 2 and 3-Soil/Water/Uranium ….....................................................................................18

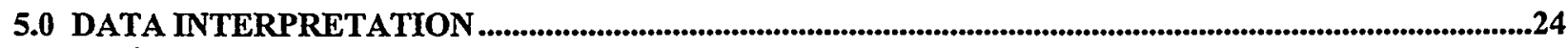

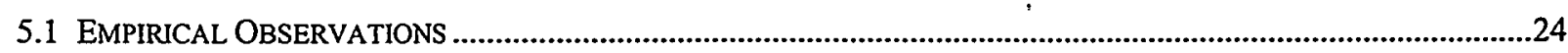

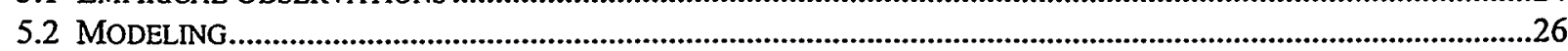

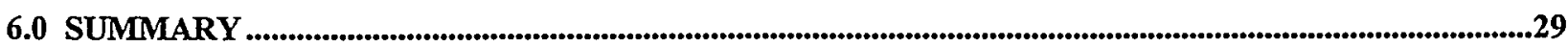

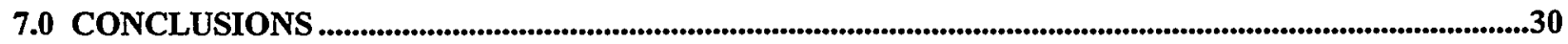

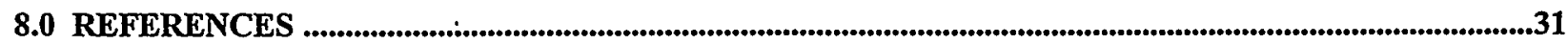




\section{LIST OF FIGURES}

FIGURE 1. SLED TRACK URANIUM SAMPLES, BACKSCATTERED SEM IMAGE. THE BRIGHT AREAS ARE URANIUM ALLOYS, AND THE DARKER GRAY REGIONS ARE URANIUM OXY-HYDROXIDES. NUMBERS REFER TO SEM/EDS ANALYSIS POINTS DISCUSSED IN TEXT. FIGURE 1B IS A CLOSE-UP OF FIGURE 1A.........................5

FIGURE 2. SAME SAMPLE AS FIGURE 1A, BUT IMAGED USING SECONDARY ELECTRONS...........................................7

FIGURE 3. BACKSCATTERED ELECTRON MICROGRAPH OF THE SAMPLE USED FOR ELECTRON MICROPROBE ANAL YSES (TABLE 1). THE ANALYSIS POINTS ARE DESIGNATED “O” FOR OXIDE PHASE, AND "M" FOR METALLIC PHASE.

FIGURE 4. ELECTRON MICROPROBE ELEMENTAL MAPS, CORRESPONDING TO SAMPLE IN FIGURE 3. BRIGHTER AREAS CORRESPOND TO HIGHER CONCENTRATIONS OF THE INDICATED ELEMENT.

FIGURE 5. X-RAY DIFFRACTION TRACES OF FINES DRIFTED ONTO A GLASS SLIDE (5A, TOP) AND PACKED INTO AN ALUMINUM WELL SLIDE (5B, BOTTOM).

FIGURE 6. EXPERIMENT \#2: CATION (6A, TOP), ANION (6B, MIDDLE) AND TOTAL URANIUM (6C, BOTTOM) CONCENTRATIONS IN AQUEOUS PHASE AS FUNCTIONS OF TIME. LEFT: LINEAR Y-AXIS. RIGHT: LOG Y-AXIS.

FIGURE 7. EXPERIMENT \#3: CATION (7A, TOP), ANION (7B, MIDDLE) AND TOTAL URANIUM (7C, BOTTOM) CONCENTRATIONS IN AQUEOUS PHASE AS FUNCTIONS OF TIME. LEFT: LINEAR Y-AXIS. RIGHT: LOG Y-AXIS.

URE 8. CALCULATED METALS CONCENTRATIONS (LINES) AND CONCENTRATIONS DETERMINED IN EXPERIMENTS 2 AND 3 (SYMBOLS); SQUARES=CA, STARS=NA, FILLED CIRCLES=K, AND RABBITS=U. THE CA, NA AND K EXPERIMENTAL VALUES ARE IN REASONABLE AGREEMENT WITH THE CALCULATIONS, BUT THE URANIUM EXPERIMENTAL VALUES ARE $\approx 1.5$ ORDERS OF MAGNITUDE LOWER THAN THE PREDICTIONS.27

\section{LIST OF TABLES}

TABLE 1. MICROPROBE ANALYSES OF URANIUM PHASES

TABLE 2. FLUID ANALYSIS RESULTS..

TABLE 3. EVAPORATION RATIOS FOR EXPERIMENTS 2 AND 3

TABLE 4. CALCULATED TIMES TO DISSOLVE ALL SCHOEPITE, T=25 ${ }^{\circ}$, 0.2 ATM $O_{2}$ 


\section{Acknowledgements}

The authors wish to acknowledge the support of the Greater Confinement Disposal project and the U.S. Department of Energy under Contract DE-AC04-94AL85000 to Sandia National Laboratories. 


\subsection{INTRODUCTION}

In the United States, there are many actinide-contaminated wastes that are associated with classified processes; included are plutonium- and uranium-tainted residues from nuclear weapons accidents, and from manufacture and disassembly of weapons. These wastes may not be placed in commercial or federal sites that require full disclosure. Furthermore, the actinide content requires special methods to assure safe long-term disposal. One method considered by the U.S. Department of Energy is the Greater Confinement Disposal concept (GCD; Chu and Bernard, 1991), which places the waste in deep $(37 \mathrm{~m})$ boreholes in unconsolidated alluvium at the Nevada Test Site (NTS). This site is dry $(\approx 13 \mathrm{~cm}$ precipitation / yr), and the water table is $\approx 200$ $\mathrm{m}$ below the boreholes. Existing GCD boreholes contain $\approx 4 \mathrm{~kg}$ plutonium, and at least $10^{3} \mathrm{~kg}$ uranium.

Federal regulations for the disposal of transuranic waste require completion of a performance assessment (PA). The PA identifies processes and events that affect the disposal system, models those events and processes, and ultimately estimates the impact to groundwater, doses and the cumulative release of radionuclides from the site, along with the associated uncertainties, for periods of $\approx 10^{4}$ years (Recard, 1995). To complete a PA for the GCD site, it is necessary to set limits on the behavior of the actinide source term, particularly the dissolution rates and solubilities of the components. However, little has been published on the nature of actinides from nuclear weapons accidents; most of the waste descriptions are classified, or vague and incomplete. Thus it is difficult to predict the degradation rates of weapons components in the GCD soils, or even to know the chemical form of the waste. In addition, the large amount of buried uranium has the potential to affect plutonium chemistry indirectly, by consuming oxygen and altering pore water chemistry.

One possible solution is to obtain degradation rates and waste behavior from analogues. Most "natural analogues" -- such as uranium ores -- are probably inappropriate, because they are so unlike weapons accident residues. Ores tend to be near equilibrium with their environments, reflecting the local oxidation potential, and have formed fairly insoluble materials by interaction with decay lead and vanadate, phosphate and molybdate. In contrast, the accident residues and GCD uranium waste were initially reactive, low-valent oxides or metals (zero-valent), and were placed amid relatively oxygen-rich sediments, where they are grossly out of chemical equilibrium.

There are, however, a few man-made analogues that probably match the GCD conditions quite well. At the Sled Track site in Kirtland Air Force Base (KAFB, in Albuquerque, New Mexico), weapons mock-ups were fired at solid targets. The metallic uranium from these tests experienced explosions and fragmentation (analogous to processes affecting accident residues at GCD), and has been buried in desert soils for up to 40 years. The report discusses the fate of the sled track uranium, including the corrosion phases formed, and the solubility and dissolution rates, as measured from lab experiments. The experimental data are compared against the results of the EQ3/6 reaction path code (Wolery, 1992; Wolery and Davelar, 1992), and the implications for future modeling and experimental work are discussed. 


\subsection{BACKGROUND}

The depleted uranium (DU) used in this investigation originated as nose cone counterweights and mock ordinance in the sled track experiments in Technical Area III at Sandia National Laboratory (SNL). These tests have continued intermittently since 1951. Release of the depleted uranium (and other associated metals) occurred as a result of the sled payload and test equipment impacting into a soil berm or concrete barrier. Although the area was subsequently remediated, at the time of this study (1993) a contaminated area still existed that covered a roughly circular region approximately 2700 feet in radius at the south end of the track (SNLA, 1993). Debris released in the tests ranged from large pieces to dust sized particles. Subsequent to this dispersal a significant fraction of the uranium has oxidized. In this regard the material being studied is thought to resemble the bulk of the uranium and plutonium inventory at the GCD site.

Traditional studies of uranium in the environment focus on the chemistry of weathering ore deposits (Pearcy et al., 1994; Garrels and Christ, 1965). DOE disposal sites differ from ore deposits in that: (1) natural uranium occurrences have had many centuries to equilibrate with near-surface environmental conditions; (2) uranium ores have more complex chemistries than materials dispersed by various military activities; and (3) weapons components often contain metallic (zero-valent) actinides, whereas the lowest oxidation state normally found in ores is U(IV). However, since both classes of materials will be affected by oxidation in near surface environments the fate of weathered uranium ores can, in some circumstances, give a long term perspective to the fate of dispersed $U$ ordinance.

In particular, studies on weathered uranium deposits attest to the general mobility of dissolved uranium in oxidizing ground waters, and highlight formation of the carbonate complexes as a cause of enhanced solubility. These studies also demonstrate that when uranium-rich fluids encounter abundant organic materials, reduction of $\mathrm{U}^{6+}$ to $\mathrm{U}^{4+}$ will effectively precipitate the uranium from solution. Under less reducing conditions uranium mobility may be limited by a number of sparingly soluble uranyl minerals typically involving an alkali earth cation, and possibly other anions derived from the uranium ore $\left(\mathrm{VO}_{4}^{3-}, \mathrm{PO}_{4}^{3-}, \mathrm{AsO}_{4}^{3-}\right.$ and $\left.\mathrm{CO}_{3}{ }^{3}\right)$

\subsection{EXPERIMENTAL}

Several methods were use to assess the fate of the uranium dispersed through the sled-track soils. These methods can generally be subdivided into "characterization" activities and lab bench "simulation" studies. Oxidized uranium metal from the sled track was characterized by several non-destructive analytical techniques. Then, uranium mobility in the soils was simulated experimentally by leaching mixtures of soil and sled track uranium. Variations in dissolved uranium concentrations and general fluid chemistry were monitored over time. 


\subsection{Characterization of Alteration Phases and Soil Minerals}

Samples of the corroded uranium were hand-picked from soils collected at the south end of the "long sled track" described by SNLA (1993). In 1993, there was a concrete and earthen barrier at the south end of the track; we reference sample locations relative to this barrier. These uranium-contaminated soils were obtained from a raised soil platform $\approx 10$ to $30 \mathrm{~m}$ east of the barrier. The uranium occurred as irregularly shaped nuggets ranging in size from $<1 \mathrm{~mm}$ to $1 \mathrm{~cm}$ in diameter. Typically nugget surfaces were coated with a fine-grained irregular yellow powdery material, while the interior contained relics of the original uranium metal. Several $\mathrm{mm}$ - to $\mathrm{cm}$ sized pieces were mounted in epoxy, ground and polished with $1 \mu \mathrm{m}$ to $0.05 \mu \mathrm{m}$ alumina to expose cross sections of the nuggets. These mounts were analyzed using both a scanning electron microscope (SEM) and electron microprobe (EMP).

The energy dispersive spectrometer (EDS) on the SEM was used to determine an approximate bulk composition for the primary uranium oxide alteration products and to determine if silicate or carbonate alteration phases were present. The samples were also examined in backscattered mode (BSM) with the object of determining the spatial distribution of the alteration products with respect to the residual uranium metal. The backscattered signal is sensitive to the average atomic number of the spot being examined. Thus, zones rich in heavy elements (e.g. uranium metal) show up as white or light gray in the backscattered image, and zones with high oxygen or water contents show up in shades of darker gray.

These same mounts were also analyzed by EMP. The EMP can provide quantitative bulk chemical compositions to aid identification of the alteration phases. In addition, elemental maps of the samples were obtained to determine the spatial distribution of the uranium alteration phases in the sample. The EMP also suffers from an inability to analyze light elements so the presence of oxygen had to be estimated based on the assumed valence of the metals that were detected. However, the analysis procedure can provide a self-consistency check, in that iteration of the instrumental corrections (which account for adsorption, fluorescence and atomic number differences relative to the standards) should produce analytical totals of $100 \%$.

Bulk phase identification was accomplished by X-ray diffraction (XRD). The uranium samples were prepared for XRD using two techniques. One sample was ground lightly, in a mortar with acetone, to concentrate selectively the fine-grained alteration material. The coarser, harder pieces were removed. The fines were then settled out of the acetone slurry solution onto a glass slide for analysis (this technique is sometimes called "drifting"). This method results in a thin mount with a relatively low surface profile for analysis, but the coarser pieces of the sample are not represented. A second mount was prepared in which the bulk sample was ground coarsely to obtain a more complete representation of the sample. No effort was made to segregate the particles by size. This roughly-ground material was then packed directly into an aluminum well slide for analysis. The disadvantage to this approách is that the surface of the sample is somewhat irregular so that the peaks could be broadened, or be displaced from the true $2 \theta$ positions, particularly in the low-angle region of the diffraction trace. In addition, XRD traces were also obtained for samples of the sled track area soil from the same general location as the oxidized uranium samples. For the latter samples, XRD patterns were obtained both before and after treatment with dilute hydrochloric acid to discern the presence of solid carbonates. 


\subsection{Solubility Experiments}

\subsubsection{Experimental Design}

Three experiments were performed to study soil-water interactions. In each case the experiment involved placing about $100 \mathrm{~g}$ soil with $500 \mathrm{~g}$ of deionized water. In experiment 1 , no uranium was present. In experiment 2 only sled track uranium was added while in the third experiment a piece of uranium metal wire augmented the sled track area uranium. In all three cases, air was bubbled through the soil mix the fluids and maintain the ambient $\mathrm{CO}_{2}$ pressure.

The first experiment was carried out primarily to test analytic and sampling procedures.

Representative, surficial soil was obtained $\approx 26 \mathrm{~m}$ west of the sled track barrier (impact area). Prior to starting this experiment it was noticed that the soil contained fragments of plant material, the larger pieces of which were removed from the soil by hand. The soil was then sterilized and dehydrated by heating it in an open container for 72 hours at $100^{\circ} \mathrm{C}$. A slurry was then prepared from deionized water $(505.2 \mathrm{~g}$ initially) and dried soil $(100.2 \mathrm{~g})$. Air was bubbled continuously through the mix to agitate the slurry and prevent the build-up of carbon dioxide. In an attempt to minimize evaporation, the beaker was sealed at the top with parafilm. In addition, the sample was weighed daily before and after sample removal and the weight of water lost to evaporation was determined and replaced. Leachate samples $(10 \mathrm{~mL})$ were taken daily. Samples were taken daily for 5 days and then less frequently for the following 6 days. The samples were withdrawn by pipette, passed through 0.25 micron filters to remove particulates, and collected in sealed sample containers. The $\mathrm{pH}$ of the slurry was measured immediately after disconnecting the stirring apparatus each time a sample was withdrawn. The $\mathrm{pH}$ was measured in-situ using a microprocessor-based $\mathrm{pH}$ probe with an ISFET sensor (UniFET ${ }^{\mathrm{TM}}$ ) with automatic temperature compensation. The sensor was calibrated with two standard solutions (Fisher brand, $\mathrm{pH} 4.00$ and 7.00) before each measurement.

Depleted uranium was added to the second and third experiments. To minimize contamination, the soil was obtained by digging back $\approx 30 \mathrm{~cm}$ into the bank of an arroyo located $15 \mathrm{~m}$ southwest from the impact barrier. Soil masses (100.4 $\mathrm{g}$ for experiment $2,100.2 \mathrm{~g}$ for experiment 3 ) and water masses ( $503.4 \mathrm{~g}$ for experiment 2 , and $503.8 \mathrm{~g}$ for experiment 3 ) were similar. No macroscopic plant fragments were noted in these soils. Ground sled track uranium fragments were mixed with the soil in both experiments prior to adding the water. The fragments were obtained by crushing nuggets from the sled track with an alumina mortar and pestle; the oxide coatings readily disaggregated, probably along cracks like those visible in figure 1 . A small piece of depleted uranium wire $(1.527 \mathrm{~g})$ was added to experiment 3 , as a test of metallic corrosion rates on a well-defined geometry; however, due to funding and ES\&H (environmental safety and health) constraints, the wire was never analyzed. For both experiments 2 and 3 , the sampling and $\mathrm{pH}$ measurements were similar to experiment 1 , but the flasks were sealed with rubber stoppers rather than covered with parafilm. To reduce the evaporation observed in experiment 1 , air was first bubbled through a column of deionized water before being passed through the soil-water slurry; the intent was to pre-saturate the air with water. However, there was still considerable evaporation of the fluid phase. Thus, these experiments may mimic the 
chemical changes expected during periodic wetting and drying of desert soils.
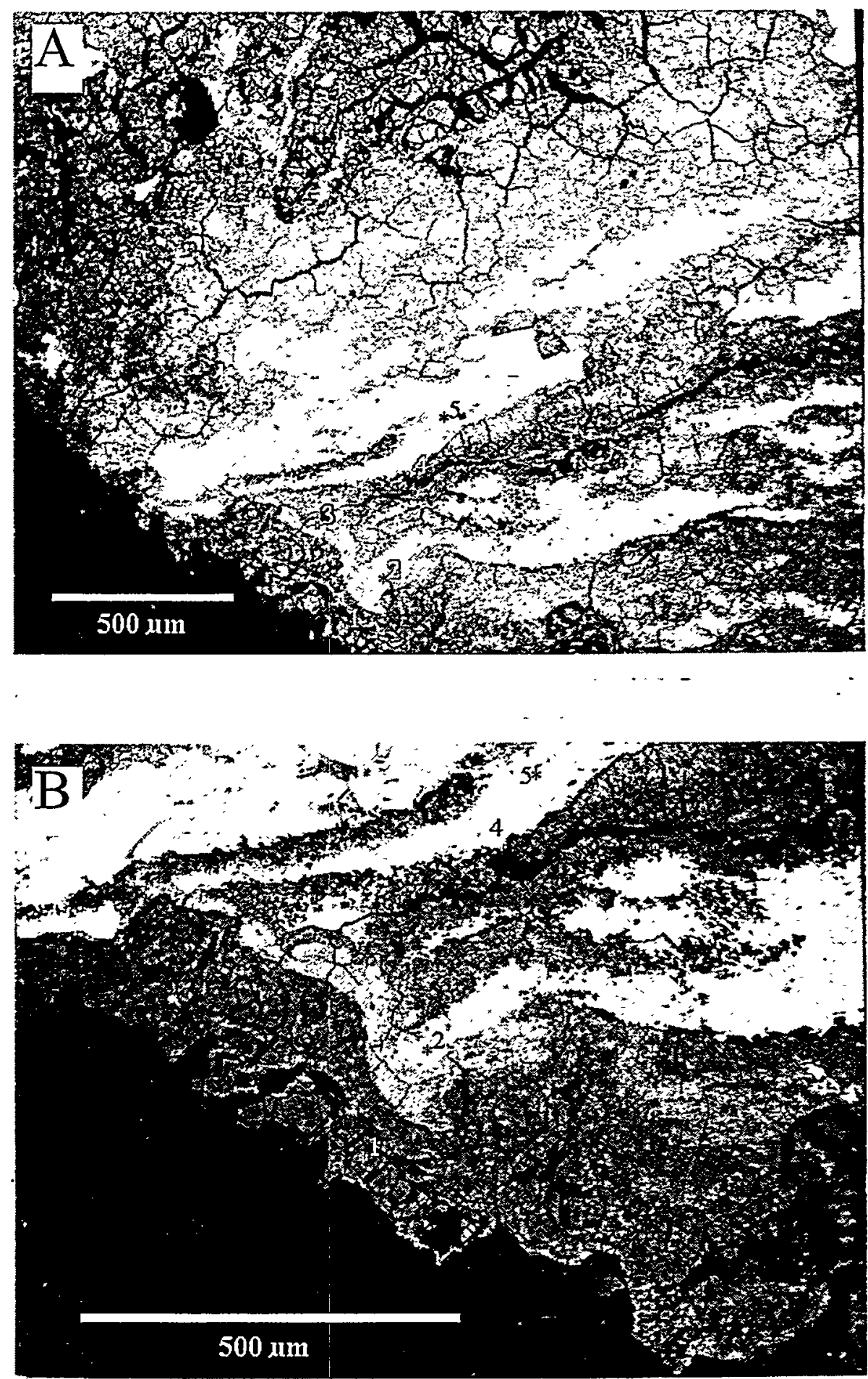

Figure 1. Sled track uranium samples, backscattered SEM image. The bright areas are uranium alloys, and the darker gray regions are uranium oxy-hydroxides. Numbers refer to SEM/EDS analysis points discussed in text. Figure 1B is a close-up of figure 1A. 


\subsubsection{Water Chemistry}

The $\mathrm{pH}$, anion and cation concentrations are the primary factors affecting uranium mobility. Cation concentrations in the liquid were determined using direct current plasma (Spectraspan-7 $\mathrm{DCP}$ ) and the anion concentrations using ion chromatography (IC). Approximately $5 \mathrm{~mL}$ of leachate was used for DCP analysis and $<1 \mathrm{~mL}$ for IC analysis. The methods used follow GCD operating procedures for these instruments (Kimball and Stockman, 1992; Krumhansl, 1992). The samples were not diluted before analysis. Dissolved carbonate was not determined directly but was evaluated using two approaches. In the first approach, charge balance in the fluid was used to calculate bicarbonate. In the second approach, bicarbonate was calculated based on the presumption of equilibration with atmospheric carbon dioxide and calcite.

Samples were also analyzed for uranium by instrumental neutron activation analysis (INAA). The INAA analyses were conducted by an outside firm (XRAL Services, Ann Arbor, Michigan) with a reported sensitivity of $0.1 \mathrm{ppm}$. The samples were prepared by pipetting $1 \mathrm{~mL}$ of the liquid into a low-background polyethylene vial. Analyses involved counting ${ }^{239} \mathrm{~Np}$, a gammaemitting daughter of ${ }^{239} \mathrm{U}$, which was in turn produced by activation of ${ }^{238} \mathrm{U}$. The analyses assumed a daughter ratio of $\mathrm{U}^{238} / \mathrm{U}^{235}$ to be that of naturally occurring uranium material ( 99.3 percent). Depleted uranium has a slightly different ratio ( $99.5-99.6$ percent) but the difference is insignificant relative to the sensitivity of the measurements. XRAL uses international rock standards for calibration.

\subsection{RESULTS}

\subsection{SEM/EDS Analyses}

The polished, mounted samples were examined under the SEM in both the normal and backscattered electron mode, at an accelerating potential of $20 \mathrm{KV}$. The latter mode provides the clearest definition of sample chemistry (figures $1 \mathrm{~A}, \mathrm{~B}$ ). In this mode the brightest areas have the highest net atomic weight, and hence are ascribed to uranium metal alloys. Progressively darker areas presumably represent successively higher oxygen or water contents. These figures show the relationship of uranium metal to the alteration material. Various shades of gray are evident in the regions surrounding the relatively unaltered, "white" metal. These gradations in intensity presumably indicate differences in the degree of hydration and alteration of the uranium. In addition to varying degrees of oxidation, these studies reveal that the samples are dissected by a network of cracks that may result from the multiple hydration-dehydration cycles, or just volume increases that accompanied oxidation of the uranium metal. The larger primary cracks extend across the sample and in some places separate pieces of uranium from the main section. The secondary cracks are smaller and more numerous and appear to be filled with amorphous or microcrystalline alteration phases. Figure 2 shows the same samples in "normal" SEM mode (imaged with secondary electrons, instead of backscattered electrons); in this mode, the smooth, polished uranium-rich areas appear dark. The rougher areas represent alteration minerals filling 
the cracks and gaps between the metallic portions.

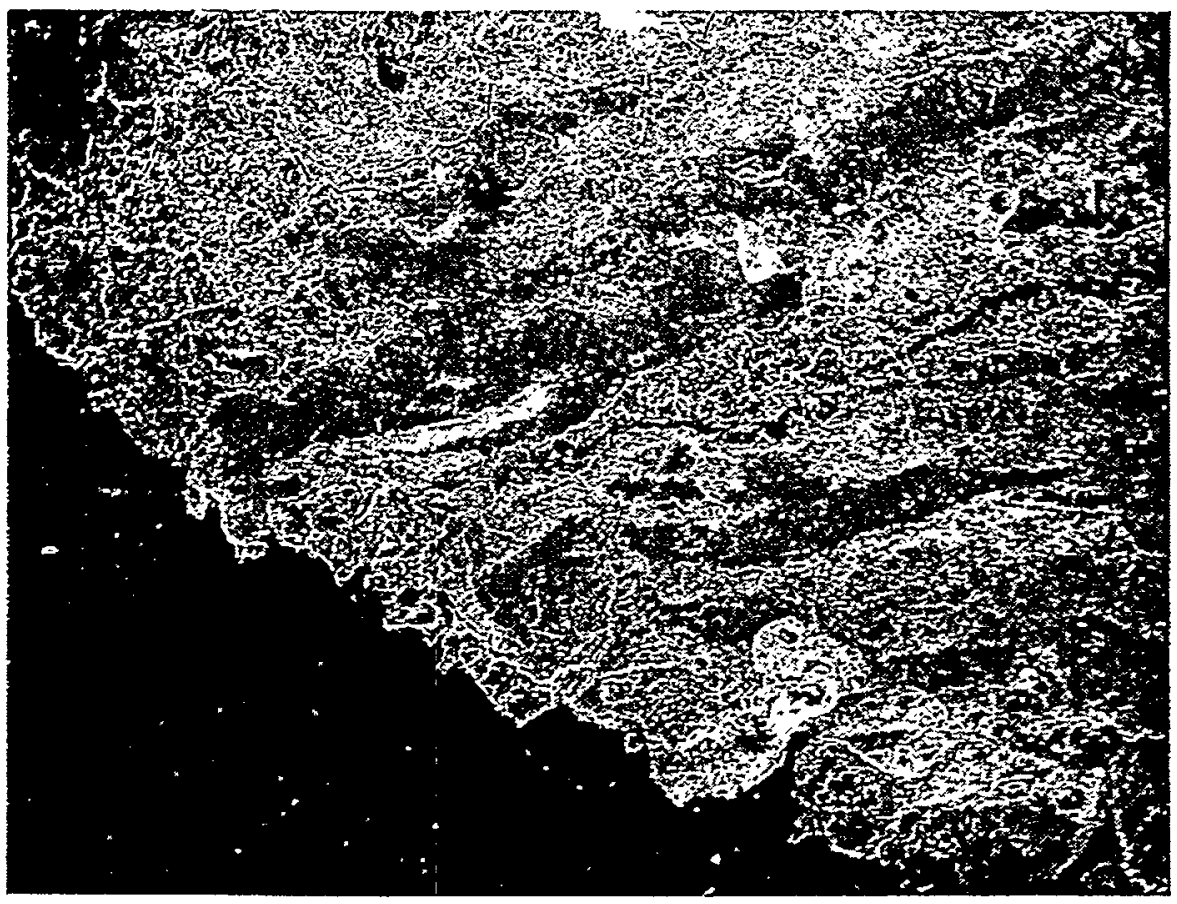

Figure 2. Same sample as figure 1A, but imaged using secondary electrons.

Inferences regarding the relative oxidation states observed in the backscattered electron photographs were confirmed using the energy dispersive (EDS) capabilities of the SEM. The EDS produces a spectrum of X-ray peaks with energies that correspond to elements in the sample. The height of a peak is roughly proportional to the abundance of the corresponding element. In particular, it was possible to note systematic differences in the relative peak heights of uranium and oxygen for the various locations noted in figures $1 \mathrm{~A}$ and $1 \mathrm{~B}$. Locations (2) and (5) in the lighter regions have high U/O peak height ratios, thus supporting the conclusion that these regions are relatively unaltered uranium metal. Points (1) and (6) are located in the highly fractured region and have U/O peak height rations of $\sim 3$. Analyses of the points ((4),(7)) from the highly altered material bordering the cracks have U/O peak height ratios of $\sim 1$. Point (3), located in a region of intermediate intensity between that of the metal and the darker gray material ((1), (6), (4), (7)) has a peak height ratio of $\sim 4$.

\subsection{Electron Microprobe (EMP) Analyses}

Further quantitative analysis of a single polished sample was conducted on the EMP in the Earth and Planetary Sciences Department at the University of New Mexico. The locations of analyses are shown on the map in figure 3. This is the same region of the sample analyzed by the SEM, although the image is rotated $180^{\circ}$ relative to that in figure1; the image is once again taken in the backscattered mode (i.e. U metal lightest). The analyses calculated in terms of the major element oxides are shown in table 1 . The two uranium metal analyses $(M-1, M-2)$ have low totals, suggesting that even the areas that appear as uranium metal are partially oxidized; this result is 
expected, since polished uranium samples oxidize rapidly. Approximately 5 percent niobium is present in the least oxidized portion of the sample. Records (SNLA, 1993) indicate that niobium was a normal component of the alloy used in testing.

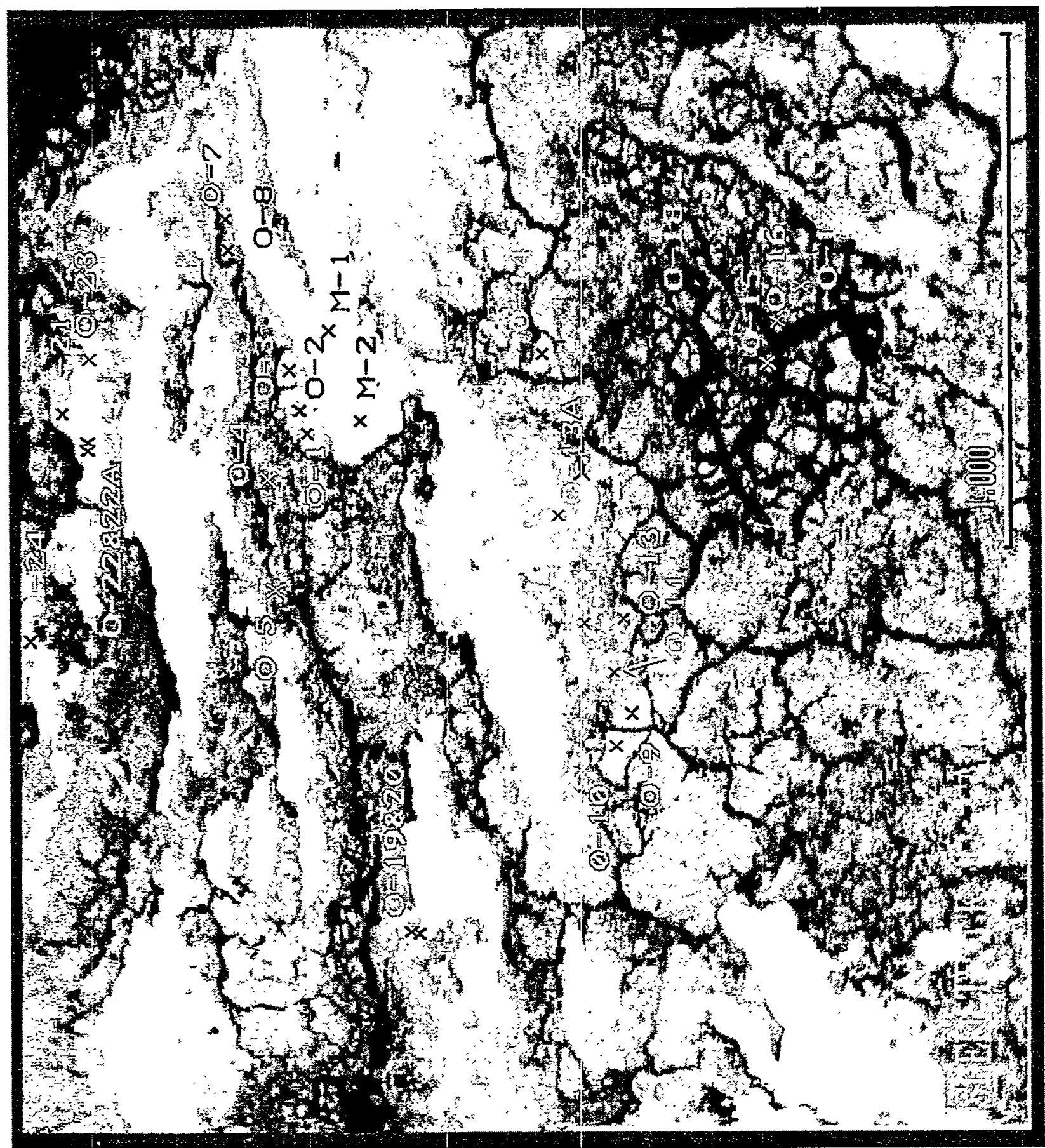

Figure 3. Backscattered electron micrograph of the sample used for electron microprobe analyses (table 1). The analysis points are designated " $O$ " for oxide phase, and " $M$ " for metallic phase. 
The oxide analyses were initially calculated with uranium assumed to be in the form of $\mathrm{UO}_{3}$. The results indicate that the sample contains $<1$ weight percent $\mathrm{SiO}_{2}$ with most locations having $<<1$ weight percent. Niobium contents range from $<1$ weight percent to 17.3 percent with a mean value of 5.3 weight percent. The variation of niobium contents shows little correlation with position or backscatter image intensity within the sample. The highest niobium concentrations were found in the densely cracked portion in the lower region of the map in figure 3 , consistent with the elemental maps of figure 4 . The irregular distribution may reflect compositional inhomogeneities in the original U-Nb alloy. 


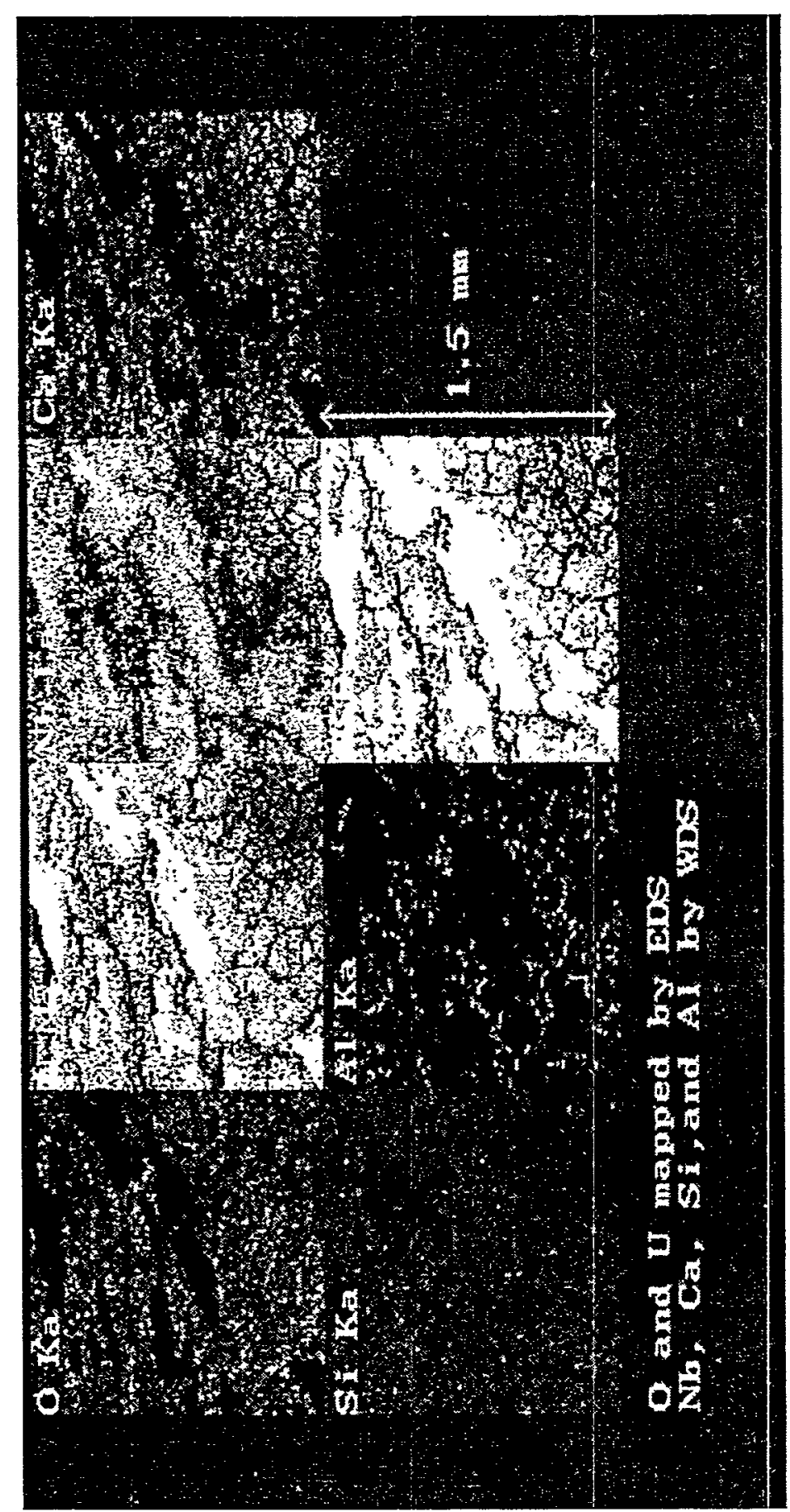

Figure 4. Electron microprobe elemental maps, corresponding to sample in figure 3. Brighter areas correspond to higher concentrations of the indicated element. 
The calcium oxide $(\mathrm{CaO})$ contents are less than 2 weight percent for all locations, with no clear correlation between calcium content and position in the sample (except that the metallic alloy is relatively Ca-free). Thus, it appears that the bulk of the altered material consists mostly of uranium (and niobium) oxides. In the relatively Ca-rich regions, $\mathrm{Ca}$ could be present as $\mathrm{CaCO}_{3}$, or as a structural component of the uranium oxides. In particular, becquerelite

$\left(\mathrm{CaO} \cdot\left(\mathrm{UO}_{3}\right)_{6} \cdot 11 \mathrm{H}_{2} \mathrm{O}\right)$ contains only $2.8 \% \mathrm{CaO}$ by weight, and forms readily from alteration of uranium oxides (Sandiano and Grambow, 1994; Sowder et al. 1996). The average $\mathrm{CaO}$ content in table $1,0.915 \%$, could imply that $1 / 3$ of the oxidized uranium is present as bequerelite. Points (7), (8), (17), and (18) have elevated weight percent calcium and low overall weight percent totals; however, bequerelite contains about $10 \%$ water, which would not be detected directly in the analysis.

In table 1 , the weight percent of the oxides is determined assuming all uranium occurs as $\mathrm{UO}_{3}$. The analyses for points (9)- (11) and (20)- (23) calculated in terms of $\mathrm{UO}_{3}$ gave totals significantly in excess of 100 percent. Several of these were recalculated assuming instead that the uranium is present as $\mathrm{UO}_{2}$ and the resulting totals were less than 100 percent. At these locations where the totals are low, when calculated assuming $\mathrm{UO}_{2}$, and high when calculated assuming $\mathrm{UO}_{3}$, it appears that the uranium occurs as hydrous $\mathrm{UO}_{2}$ or as $\mathrm{UO}_{2+\times}$, compounds, where $\mathrm{x}<0.25$. 
Table 1. Microprobe Analyses Of Uranium Phases

Uranium Metallic Alloys Expressed as Weight Percent of the Elements

\begin{tabular}{|l|l|l|l|l|l|l|l||}
\hline Point \# & $\mathrm{Al}$ & $\mathrm{Si}$ & $\mathrm{Ca}$ & $\mathrm{Nb}$ & $\mathrm{U}$ & $\mathrm{O}^{*}$ & Total \\
\hline 1 & nd & 0.01 & nd & 4.86 & 91.37 & nd & 96.23 \\
\hline 2 & 0.006 & 0.01 & nd & 5.19 & 91.17 & nd & 96.36 \\
\hline
\end{tabular}

Uranium Oxides Expressed as Weight Percent of the Elements

\begin{tabular}{|l|l|l|l|l|l|l|l||}
\hline Point \# & $\mathrm{Al}$ & $\mathrm{Si}$ & $\mathrm{Ca}$ & $\mathrm{Nb}$ & $\mathrm{U}$ & $\mathrm{O}^{*}$ & Total \\
\hline 1 & $\mathrm{nd}$ & 0.02 & 0.258 & 5.17 & 73.5 & 17.1 & 96.03 \\
\hline 2 & 0.19 & $\mathrm{nd}$ & 0.45 & 3.98 & 71.6 & 16.5 & 93.7 \\
\hline 3 & nd & 0.08 & 0.43 & 5.27 & 74.3 & 17.5 & 97.5 \\
\hline 4 & 0.04 & 0.03 & 0.22 & 2.08 & 77.7 & 16.7 & 96.8 \\
\hline 5 & 0.02 & 0.16 & $\mathrm{nd}$ & 0.06 & 80.3 & 16.4 & 96.8 \\
\hline 6 & 0.07 & 0.03 & 0.35 & 4.38 & 71.1 & 16.6 & 92.4 \\
\hline 7 & nd & 0.05 & 1.40 & 0.68 & 74.5 & 15.9 & 92.6 \\
\hline 8 & 0.001 & 0.03 & 1.14 & 3.87 & 75.1 & 17.3 & 97.4 \\
\hline 9 & 0.05 & 0.14 & nd & 1.06 & 82.8 & 17.3 & 101.4 \\
\hline 10 & nd & 0.02 & nd & 1.52 & 84.6 & 17.7 & 103.8 \\
\hline 11 & 0.04 & nd & 0.23 & 1.80 & 80.8 & 17.2 & 100.0 \\
\hline 12 & nd & nd & 0.28 & 3.93 & 75.9 & 17.1 & 97.2 \\
\hline 13 & nd & 0.01 & 0.66 & 5.51 & 73.4 & 17.4 & 97.0 \\
\hline 14 & 0.004 & 0.06 & 0.63 & 2.39 & 75.1 & 16.5 & 94.7 \\
\hline 15 & 0.01 & 0.11 & nd & 0.73 & 84.5 & 17.5 & 102.8 \\
\hline 16 & 0.003 & 0.03 & 0.54 & 1.19 & 68.2 & 14.5 & 84.5 \\
\hline 17 & 0.002 & 0.05 & 1.05 & 12.11 & 62.3 & 18.3 & 93.8 \\
\hline 18 & nd & 0.05 & 1.09 & 11.67 & 61.2 & 17.9 & 91.9 \\
\hline 198 & 0.004 & 0.04 & 0.46 & 7.41 & 52.6 & 14.0 & 74.5 \\
\hline 20 & 0.08 & 0.29 & 1.12 & 2.06 & 82.1 & 18.3 & 103.9 \\
\hline 21 & 0.12 & 0.42 & 0.97 & 4.83 & 82.0 & 19.6 & 107.9 \\
\hline 22 & nd & 0.06 & nd & 2.16 & 81.8 & 17.5 & 101.5 \\
\hline 23 & nd & nd & nd & 1.91 & 83.3 & 17.6 & 102.9 \\
\hline
\end{tabular}


(Table 1, continued)

Uranium Oxides Expressed as Weight Percent of Oxide Components

\begin{tabular}{|l|l|l|l|l|l|l||}
\hline Point \# & $\mathrm{Al}_{2} \mathrm{O}_{3}$ & $\mathrm{SiO}_{2}$ & $\mathrm{CaO}$ & $\mathrm{Nb}_{2} \mathrm{O}_{5}$ & $\mathrm{UO}_{3}$ & Total \\
\hline 1 & nd & 0.04 & 0.35 & 7.40 & 88.3 & 96.0 \\
\hline 2 & 0.36 & nd & 0.62 & 5.69 & 86.5 & 92.7 \\
\hline 3 & nd & 0.16 & 0.61 & 7.54 & 89.2 & 97.5 \\
\hline 4 & 0.07 & 0.07 & 0.30 & 2.98 & 93.4 & 96.8 \\
\hline 5 & 0.04 & 0.33 & nd & 0.09 & 96.4 & 96.8 \\
\hline 6 & 0.14 & 0.06 & 0.49 & 6.26 & 85.4 & 92.4 \\
\hline 7 & nd & 0.10 & 1.96 & 0.97 & 89.6 & 92.6 \\
\hline 8 & 0.001 & 0.06 & 1.59 & 5.54 & 90.2 & 97.4 \\
\hline 9 & 0.09 & 0.29 & nd & 1.51 & 99.5 & 101.4 \\
\hline 10 & nd & 0.04 & nd & 2.17 & 101.7 & 103.8 \\
\hline 11 & 0.07 & nd & 0.31 & 2.57 & 97.1 & 100.0 \\
\hline 12 & nd & nd & 0.39 & 5.63 & 91.2 & 97.22 \\
\hline 13 & nd & 0.02 & 0.92 & 7.88 & 88.2 & 97.01 \\
\hline 14 & 0.01 & 0.13 & 0.87 & 3.42 & 90.3 & 94.7 \\
\hline 15 & 0.02 & 0.24 & nd & 1.05 & 101.5 & 102.8 \\
\hline 16 & 0.005 & 0.07 & 0.76 & 1.70 & 82.0. & 84.5 \\
\hline 17 & 0.004 & 0.11 & 1.48 & 17.3 & 74.9 & 93.8 \\
\hline 18 & nd & 0.11 & 1.52 & 16.7 & 73.6 & 91.9 \\
\hline 19 & 0.007 & 0.08 & 0.64 & 10.6 & 63.2. & 74.5 \\
\hline 20 & 0.14 & 0.61 & 1.56 & 2.95 & 98.6 & 103.9 \\
\hline 21 & 0.22 & 0.89 & 1.36 & 6.91 & 98.5 & 107.9 \\
\hline 22 & nd & 0.14 & nd & 3.09 & 98.2 & 101.5 \\
\hline 23 & nd & nd & nd & 2.74 & 100.1 & 102.9 \\
\hline \hline
\end{tabular}


(Table 1, continued)

Uranium Oxide Compositions Expressed as Atoms per 5 Oxygens

\begin{tabular}{||l|l|l|l|l|l|l|l||}
\hline Point \# & Al & $\mathrm{Si}$ & $\mathrm{Ca}$ & $\mathrm{Nb}$ & $\mathrm{U}$ & $\mathrm{O}$ & $\begin{array}{l}\text { Cation } \\
\text { Totals }\end{array}$ \\
\hline 1 & nd & 0.003 & 0.03 & 0.26 & 1.44 & 5.00 & 1.73 \\
\hline 2 & 0.03 & nd & 0.05 & 0.21 & 1.46 & 5.00 & 1.75 \\
\hline 3 & nd & 0.01 & 0.05 & 0.26 & 1.43 & 5.00 & 1.75 \\
\hline 4 & 0.006 & 0.006 & 0.03 & 0.11 & 1.56 & 5.00 & 1.71 \\
\hline 5 & 0.004 & 0.03 & nd & 0.003 & 1.65 & 5.00 & 1.68 \\
\hline 6 & 0.01 & 0.005 & 0.04 & 0.23 & 1.45 & 5.00 & 1.74 \\
\hline 7 & nd & 0.008 & 0.18 & 0.04 & 1.57 & 5.00 & 1.79 \\
\hline 8 & 0.001 & 0.004 & 0.13 & 0.19 & 1.46 & 5.00 & 1.79 \\
\hline 9 & 0.008 & 0.02 & nd & 0.05 & 1.60 & 5.00 & 1.69 \\
\hline 10 & nd & 0.003 & nd & 0.07 & 1.060 & 5.00 & 1.68 \\
\hline 11 & 0.007 & nd & 0.03 & 0.90 & 1.58 & 5.00 & 1.70 \\
\hline 12 & nd & nd & 0.03 & 0.20 & 1.49 & 5.00 & 1.72 \\
\hline 13 & nd & 0.002 & 0.07 & 0.27 & 1.41 & 5.00 & 1.76 \\
\hline 14 & 0.001 & 0.01 & 0.08 & 0.13 & 1.53 & 5.00 & 1.74 \\
\hline 15 & 0.002 & 0.02 & nd & 0.04 & 1.62 & 5.00 & 1.68 \\
\hline 16 & 0.005 & 0.006 & 0.07 & 0.07 & 1.58 & 5.00 & 1.73 \\
\hline 17 & 0.003 & 0.008 & 0.12 & 0.57 & 1.15 & 5.00 & 1.84 \\
\hline 18 & nd & 0.008 & 0.12 & 0.56 & 1.15 & 5.00 & 1.84 \\
\hline 19 & 0.008 & 0.007 & 0.07 & 0.45 & 1.26 & 5.00 & 1.79 \\
\hline 20 & 0.012 & 0.04 & 0.12 & 0.10 & 1.51 & 5.00 & 1.79 \\
\hline 21 & 0.018 & 0.06 & 0.10 & 0.21 & 1.41 & 5.00 & 1.80 \\
\hline 22 & nd & 0.01 & nd & 0.11 & 1.57 & 5.00 & 1.69 \\
\hline 23 & nd & nd & nd & 0.09 & 1.59 & 5.00 & 1.68 \\
\hline \hline
\end{tabular}




\subsection{X-ray Diffraction Analyses}

All XRD patterns were reduced to peak $2 \theta$ values and the corresponding interplanar spacings ("d", in Angstroms). The d values were then compared against the card file from the Joint Committee on Powder Diffraction Standards (JCPDS, 1992).

\subsubsection{Soil Minerals}

The soil used for experiment 1 was analyzed by $\mathrm{X}$-ray diffraction, before and after treatment with dilute $\mathrm{HCl}$. The purpose of the $\mathrm{HCl}$ treatment was to determine whether calcium carbonate was present in the sample. When treated with $\mathrm{HCl}$ and water, the soil sample effervesced, a positive indication for the presence of carbonate. The XRD patterns were expected to support this observation but were inconclusive. The primary diffraction peak for calcite occurs at $2 \theta$ values of $39.4^{\circ}(\mathrm{d}=3.035 \AA)$ with lesser peaks at $29.4^{\circ}(\mathrm{d}=2.285 \AA), 43.1^{\circ}(\mathrm{d}=2.095 \AA), 47.5^{\circ}(\mathrm{d}=1.913$ $\AA$ ) and $48.5^{\circ}(\mathrm{d}=1.875 \AA)$. Diffraction peaks are present at these values of $2 \theta$ in the soil sample that was not treated with $\mathrm{HCl}$. However, the peaks do not disappear in the XRD pattern for the sample treated with $\mathrm{HCl}$. The amount of $\mathrm{HCl}$ added was calculated to be a ten-fold excess over the amount required to dissolve $10 \%$ calcite by weight; however, kinetic constraints may have prevented larger calcite pieces from dissolving. The chief soil minerals were quartz and feldspar, and several feldspar peaks overlap the calcite peaks, and the overlap makes a rigorous analysis impossible. No clay was found via X-ray diffraction, but given that this is an unoriented mount, clay could still be present in up to $10 \%$ and not be detected.

\subsubsection{Uranium Phases}

The XRD patterns from the two uranium samples are shown in figures 5A and 5B. Figure $5 \mathrm{~A}$ is the pattern for the fine powder, suspended in acetone, which was "drifted" as a thin layer onto a glass slide; figure $5 \mathrm{~B}$ is the pattern for the inhomogeneous sample packed into the aluminum well slide. Both patterns indicate the unambiguous presence of schoepite $\left(\mathrm{UO}_{3} \cdot 2 \mathrm{H}_{2} \mathrm{O}\right)$ in the samples. The primary schoepite peaks in the sample occurs at a $2 \theta$ value of $12.0^{\circ}(\mathrm{d}=7.35 \AA)$ and $12.3^{\circ}(d=7.18 \AA)$ in figures $5 \mathrm{~A}$ and $5 \mathrm{~B}$ respectively, compared with $\mathrm{d}=7.28 \AA$ in JCPDS card \# 13-407. However, the position of the low angle diffractions may be somewhat inaccurate for these samples as a result of surface irregularities. The secondary peaks occur at $2 \theta$ values of $24.3^{\circ}(\mathrm{d}=3.65 \AA), 27.9^{\circ}(3.19 \AA)$ and $36.7^{\circ}(\mathrm{d}=2.45 \AA)$ in figure $5 \mathrm{~A}$ and at $24.1^{\circ}(\mathrm{d}=3.68 \AA)$, $27.8^{\circ}(\mathrm{d}=3.20 \AA)$ and $36.3^{\circ}(\mathrm{d}=2.47 \AA)$ in figure $5 \mathrm{~B}$.

The sample mounted on the glass slide (figure $5 \mathrm{~A}$ ) also appears to contain $\mathrm{UO}_{2}$. The primary peaks are at a $2 \theta$ value of $28.8^{\circ}(\mathrm{d}=3.09 \AA)$ with secondary peaks at $32.0^{\circ}(\mathrm{d}=2.72 \AA), 46.9^{\circ}$ $(\mathrm{d}=1.94 \AA)$ and $56.4^{\circ}(\mathrm{d}=1.68 \AA)$. Both samples appear to have uranium metal in small amounts. The primary peak in figure $5 \mathrm{~A}$ is at $37.9^{\circ}(\mathrm{d}=2.37 \AA), 39.0^{\circ}(\mathrm{d}=2.31 \AA)$ and $34.8^{\circ}(\mathrm{d}=2.57 \AA)$ is at $38.2^{\circ}(\mathrm{d}=2.35 \AA)$ with secondary peaks at $34.9^{\circ}(\mathrm{d}=2.56 \AA)$ and $38.3^{\circ}(\mathrm{d}=2.35 \AA)$. The primary peak in figure $5 B$ is at $38.2^{\circ}(d=2.35 \AA)$ with a secondary peak at $34.9^{\circ}(d=2.56 \AA)$.

The possible presence of several other compounds (including $\mathrm{UO}_{2+\times}$, becquerelite $\left(\mathrm{CaU}_{6} \mathrm{O}_{19} \cdot 11 \mathrm{H}_{2} \mathrm{O}\right), \mathrm{UO}_{3}$, hydrous $\mathrm{UO}_{3}$ and $\left.\mathrm{U}_{3} \mathrm{O}_{8}\right)$ is suggested from the patterns, but it was not possible to identify these compounds with certainty. For these compounds, the peaks were 
present at the correct locations but the relative peak heights did not appear correct, or one or more diffraction peaks could not be located. Some of these peaks may reflect the presence of compounds other than uranium alteration products. Alternatively they may represent poorly crystalline uranium phases or uranium oxides that have been hydrated to varying degrees. In particular, when becquerelite dehydrates, its peaks broaden (Finch and Ewing, 1992), and intensity ratios probably change as interlayer waters are lost, so it is undoubtedly difficult to detect small amounts of this phase in X-ray patterns. 

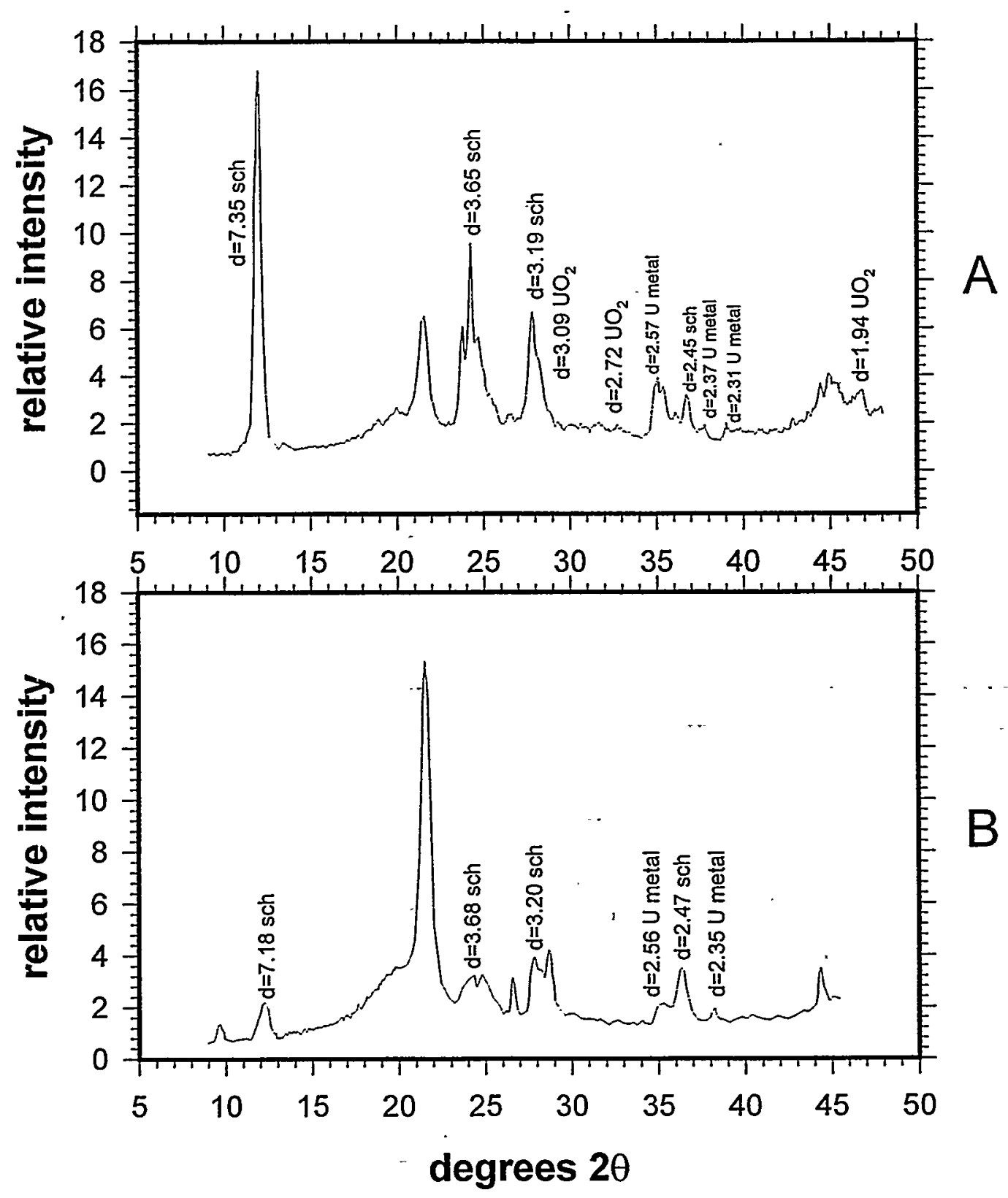

Figure 5. X-ray diffraction traces of fines drifted onto a glass slide (5A, top) and packed into an aluminum well slide (5B, bottom). 


\subsection{Solubility experiments}

\subsubsection{Experiment 1- Soil/Water}

The leachate samples from the initial soil-water experiment were analyzed to determine cation and anion concentrations as a function of time (table 2.). Over the relatively short 10 day period of this "control experiment" little change was observed in the cation concentrations. The only noteworthy features are the small excursion on day 8 for $\mathrm{Fe}, \mathrm{Ca}, \mathrm{Mg}, \mathrm{Na}$ and $\mathrm{K}$, (though the cause is unclear), and the slow increase of $\mathrm{Ca}$ over time. In addition, the relative concentrations of the various dissolved components are roughly in the range to be expected. Chloride and fluoride concentrations decreases slightly over the 10 day experiment but the overall change is less than $0.5 \mathrm{ppm}$. The chloride trend exhibits some oscillations, whereas the fluoride trend is relatively smooth. The sulfate concentration, on the other hand, increases over the 10 day period from $\approx 3.25$ to $4.5 \mathrm{ppm}$. Finally, after an initial drop, the $\mathrm{pH}$ stabilizes at the levels to be expected for air equilibrated with calcite $(\approx 8.4 ;$ Krauskopf, 1967). Thus, these results suggest that carbonate dissolution and clay-water ion exchange processes will approach equilibrium within a matter of just a few days.

\subsubsection{Experiments 2 and 3- Soil/Water/Uranium}

The results of the solubility experiments for the soil-water-uranium systems are shown in figures 6A-C and 7A-C. Major cation, anion and uranium concentrations are plotted versus time. The only intentional difference between these two experiments was the addition of a piece of DU wire $(1.527 \mathrm{~g})$ for experiment \#3. In both experiments \#2 and \#3, bromide concentrations are negligible until the final day of measurement. In both experiments, the concentrations of $\mathrm{Cl}, \mathrm{Na}$, $\mathrm{K}, \mathrm{Cl}$ and $\mathrm{F}$ anions remain relatively constant out to the 21 st day of the test. Beyond that time most elemental concentrations show a distinct increase that becomes particularly marked after day $25 . \mathrm{Ca}, \mathrm{NO}_{3}^{-}, \mathrm{SO}_{4}{ }^{-}$, and $\mathrm{U}$ show a different behavior in that their concentrations rise continuously during the test and increase markedly after day 21 of the test. 

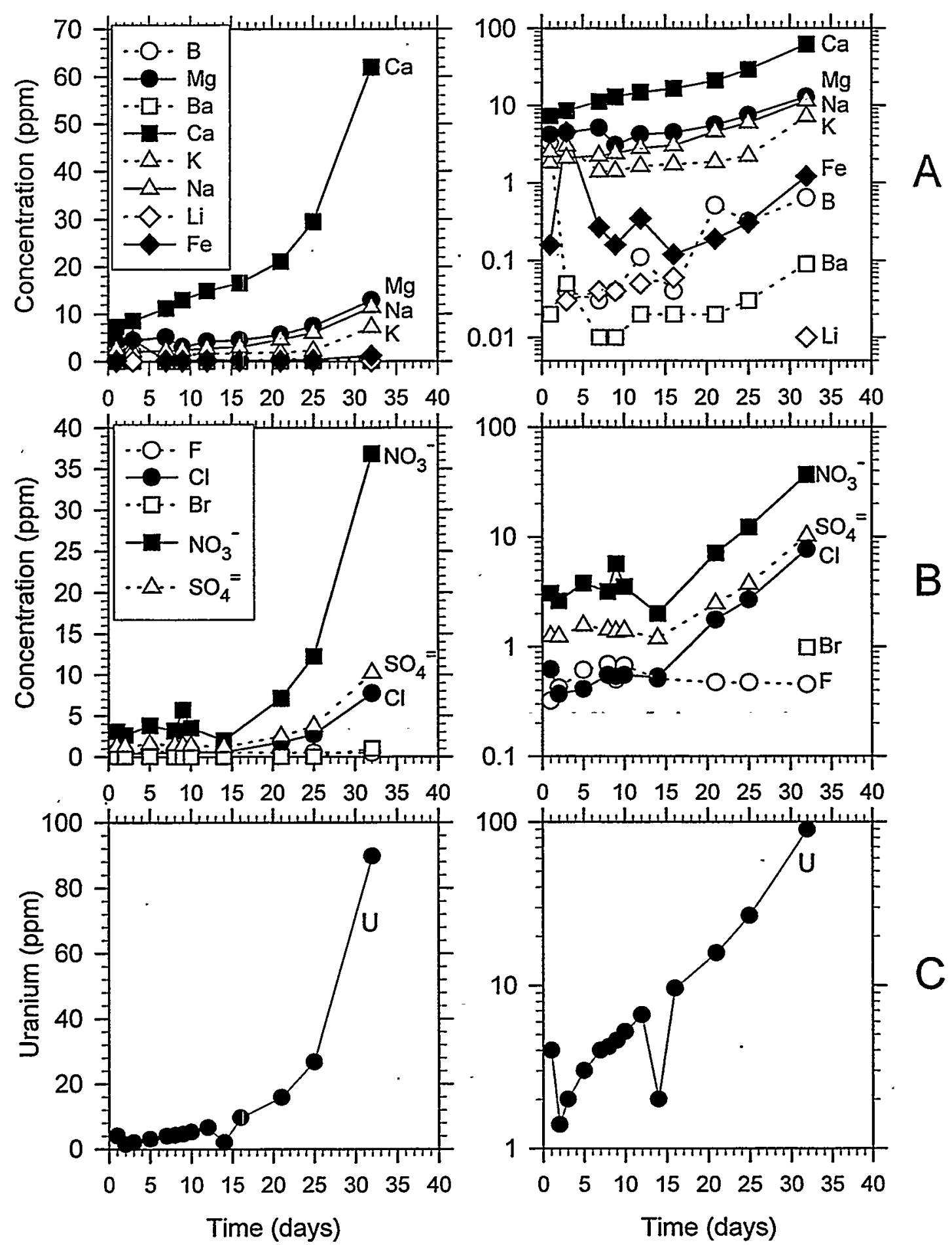

Figure 6. Experiment \#2: Cation (6A, top), anion (6B, middle) and total uranium (6C, bottom) concentrations in aqueous phase as functions of time. Left: linear y-axis. Right: $\log y$-axis. 

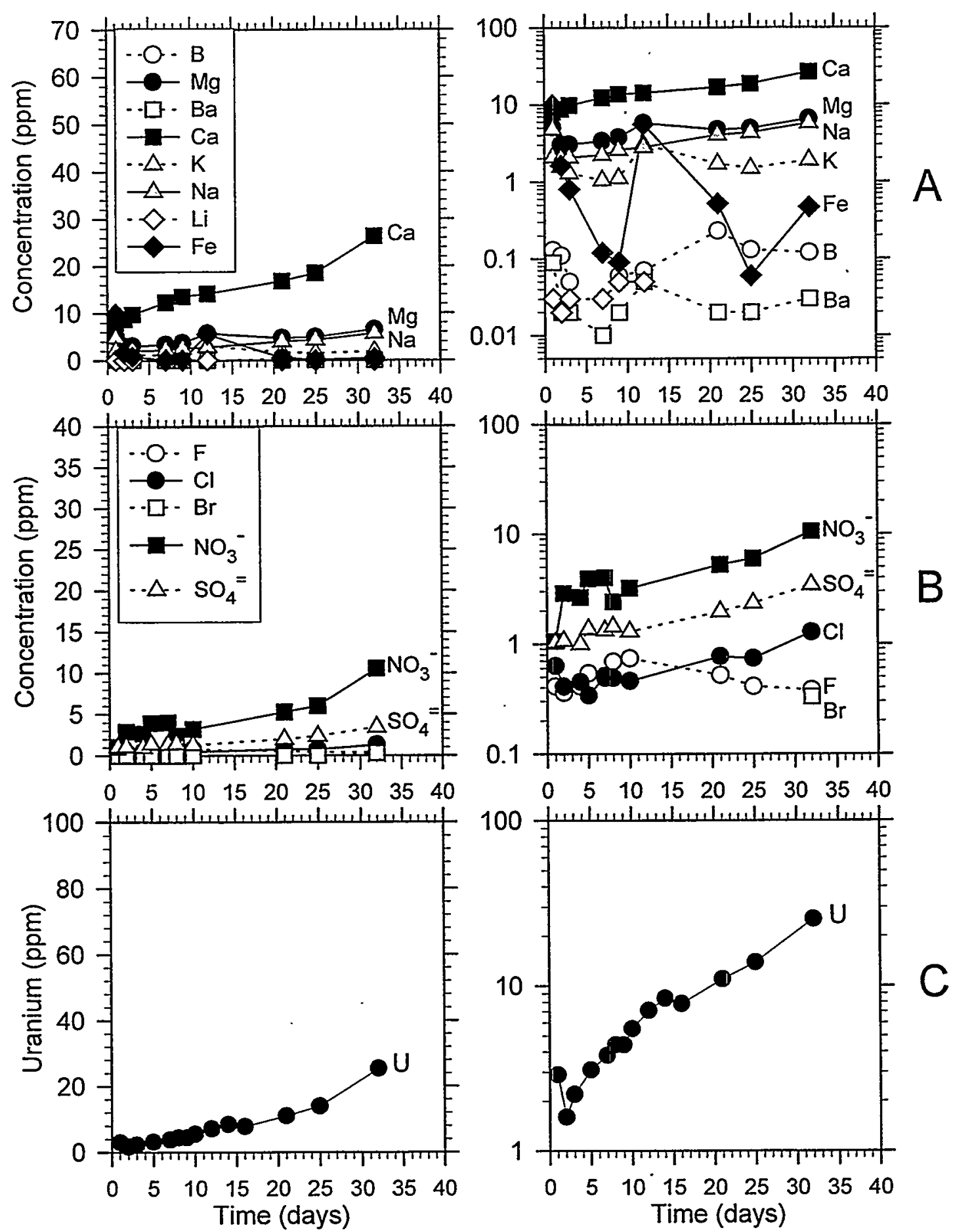

Figure 7. Experiment \#3: Cation (7A, top), anion (7B, middle) and total uranium (7C, bottom) concentrations in aqueous phase as functions of time. Left: linear $y$-axis. Right: $\log$ y-axis. 
Table 2. Fluid Analysis Results

$\mathrm{U}$ and $\mathrm{pH}$ values

\begin{tabular}{||l|l|l|l|l|l|l|l||}
\hline $\begin{array}{l}\text { Expt. 1 } \\
\text { Days }\end{array}$ & $\begin{array}{l}\text { Expt. 1 } \\
\mathrm{pH}\end{array}$ & $\begin{array}{l}\text { Expt. 2 } \\
\text { Days }\end{array}$ & $\begin{array}{l}\text { Expt 2 } \\
\mathrm{U} \mathrm{ppm}\end{array}$ & $\begin{array}{l}\text { Expt. 2 } \\
\mathrm{pH}\end{array}$ & Expt 3 Days & $\begin{array}{l}\text { Expt. 3 } \\
\text { U ppm }\end{array}$ & Expt. 3 pH \\
\hline 1 & 8.6 & 1 & 4.0 & 8.6 & 1 & 2.9 & 8.6 \\
\hline 2 & 8.6 & 2 & 1.4 & 8.3 & 2 & 1.6 & 8.3 \\
\hline 3 & 8.8 & 3 & 2.0 & 8.3 & 3 & 2.2 & 8.4 \\
\hline 4 & 8.8 & 5 & 3.0 & 8.2 & 5 & 3.1 & 8.3 \\
\hline 7 & 8.5 & 7 & 4.0 & 8.2 & 7 & 3.8 & 8.3 \\
\hline 8 & 8.5 & 8 & 4.2 & 8.4 & 8 & 4.4 & 8.3 \\
\hline 10 & & 9 & 4.6 & 8.4 & 9 & 4.4 & 8.4 \\
\hline & & 10 & 5.2 & 7.9 & 10 & 5.5 & 8.3 \\
\hline & & 12 & 6.6 & $8.3 \cdot$ & 12 & 7.1 & 8.3 \\
\hline & & 14 & 2.0 & 8.3 & 14 & 8.4 & 8.4 \\
\hline & & 16 & 9.6 & 8.3 & 16 & 7.8 & 7.9 \\
\hline & & 21 & 15.8 & 8.5 & 21 & 11.0 & 8.5 \\
\hline & & 25 & 26.7 & 8.4 & 25 & $13.9 \cdot$ & 8.3 \\
\hline & & 32 & 89.7 & 8.3 & 32 & 35.4 & 8.3 \\
\hline
\end{tabular}


(Table 2, continued)

Cations

\begin{tabular}{|c|c|c|c|c|c|c|c|c|}
\hline Days, Expt. 1 & B ppm & $\mathrm{Mg}$ ppm & Ba ppm & Ca ppm & $\mathrm{K}$ ppm & Na ppm & Li ppm & Fe ppm \\
\hline 1 & 0.13 & 3.4 & 0.07 & 18.9 & 5.3 & 3.7 & 0.10 & 0.06 \\
\hline 2 & 0.18 & 3.9 & 0.09 & 22.2 & 5.2 & 3.9 & 0.12 & 0.02 \\
\hline 3 & 0.12 & 4.7 & 0.09 & 22.4 & 5.2 & 3.9 & 0.13 & 0.01 \\
\hline 4 & 0.13 & 4.9 & 0.09 & 23.3 & 5.3 & 4.0 & 0.13 & 0.02 \\
\hline 7 & 0.12 & 5.4 & 0.10 & 24.3 & 5.0 & 4.0 & 0.15 & 0.02 \\
\hline 8 & 0.14 & 6.3 & 0.13 & 29.7 & 5.8 & 4.1 & 0.16 & 2.28 \\
\hline 10 & 0.09 & 5.5 & 0.08 & 23.1 & 5.1 & 4.4 & 0.15 & 0.06 \\
\hline Days, Expt. 2 & B ppm & $\mathrm{Mg} \mathrm{ppm}$ & Ba ppm & Ca ppm & $\mathrm{K} \mathrm{ppm}$ & Na ppm & Li ppm & $\mathrm{Fe}$ ppm \\
\hline 1 & 3.24 & 4.2 & 0.02 & 7.3 & 1.8 & 2.5 & nd & 0.16 \\
\hline 3 & 0.04 & 4.4 & 0.05 & 8.6 & 3.0 & 2.1 & 0.03 & 4.54 \\
\hline 7 & 0.03 & 5.1 & 0.01 & 11.2 & 1.4 & 2.2 & 0.04 & 0.27 \\
\hline 9 & 0.04 & 3.0 & 0.01 & 13.0 & 1.4 & 2.4 & 0.04 & 0.16 \\
\hline 12 & 0.11 & 4.2 & 0.02 & 14.9 & 1.6 & 2.8 & 0.05 & 0.35 \\
\hline 16 & 0.04 & 4.4 & 0.02 & 16.6 & 1.7 & 3.0 & 0.06 & 0.12 \\
\hline 21 & 0.51 & 5.6 & 0.02 & 21.1 & 1.8 & 4.6 & nd & 0.19 \\
\hline 25 & 0.32 & 7.4 & 0.03 & 29.5 & 2.2 & 6.0 & nd & 0.31 \\
\hline 32 & 0.64 & 12.9 & 0.09 & 62.0 & 7.2 & 11.5 & 0.01 & 1.20 \\
\hline Days, Expt 3 & B ppm & $\mathrm{Mg} \mathrm{ppm}$ & Ba ppm & Ca ppm & $\mathrm{K}$ ppm & Na ppm & Li ppm & Fe ppm \\
\hline 1 & 0.13 & 5.1 & 0.09 & 8.0 & 4.8 & 2.1 & 0.03 & 9.9 \\
\hline 2 & 0.11 & 3.0 & 0.02 & 8.7 & 1.6 & 2.0 & 0.02 & 1.6 \\
\hline 3 & 0.05 & 3.1 & 0.02 & 9.8 & 1.3 & 2.1 & 0.03 & 0.80 \\
\hline 7 & nd & 3.4 & 0.01 & 12.3 & 1.1 & 2.2 & 0.03 & 0.12 \\
\hline 9 & 0.06 & 3.7 & 0.02 & 13.6 & 1.1 & 2.6 & 0.05 & 0.09 \\
\hline 12 & 0.07 & 5.8 & 0.05 & 14.2 & 3.1 & 2.8 & 0.05 & 5.55 \\
\hline 21 & 0.23 & 4.7 & 0.02 & 16.8 & 1.7 & 4.0 & nd. & 0.52 \\
\hline 25 & 0.13 & 4.9 & 0.02 & 18.5 & 1.5 & 4.3 & nd & 0.06 \\
\hline 32 & 0.12 & 6.6 & 0.03 & 26.4 & 1.9 & 5.7 & nd & 0.47 \\
\hline
\end{tabular}


Table 2, continued

Anions

\begin{tabular}{|c|c|c|c|c|c|c|}
\hline \multicolumn{2}{|l|}{ Days, Expt. 1} & F ppm & \multicolumn{2}{|l|}{$\mathrm{Cl} \mathrm{ppm}$} & \multicolumn{2}{|c|}{$\mathrm{SO}_{4} \mathrm{ppm}$} \\
\hline \multicolumn{2}{|l|}{1} & 1.01 & \multicolumn{2}{|l|}{0.82} & \multicolumn{2}{|l|}{3.2} \\
\hline 2 & . & 1.05 & \multicolumn{2}{|l|}{1.16} & \multicolumn{2}{|l|}{3.5} \\
\hline \multicolumn{2}{|l|}{3} & 0.80 & \multicolumn{2}{|l|}{0.47} & \multicolumn{2}{|l|}{3.8} \\
\hline \multicolumn{2}{|l|}{4} & 0.79 & \multicolumn{2}{|l|}{0.59} & \multicolumn{2}{|l|}{4.0} \\
\hline \multicolumn{2}{|l|}{7} & 0.72 & \multicolumn{2}{|l|}{0.47} & \multicolumn{2}{|l|}{4.3} \\
\hline \multicolumn{2}{|l|}{8} & 0.71 & \multicolumn{2}{|l|}{0.47} & \multicolumn{2}{|l|}{4.5} \\
\hline \multicolumn{2}{|l|}{10} & 0.69 & \multicolumn{2}{|l|}{0.52} & 4.8 & \\
\hline Days, Expt 2 & F ppm & $\mathrm{Cl} \mathrm{ppm}$ & Br ppm & $\mathrm{NO}_{3} \mathrm{ppm}$ & & $\mathrm{SO}_{4} \mathrm{ppm}$ \\
\hline 1 & 0.32 & 0.62 & nd & 3.1 & & 1.3 \\
\hline 2 & 0.42 & 0.37 & nd & 2.6 & & 1.2 \\
\hline 5 & 0.61 & 0.41 & nd & 3.8 & & 1.6 \\
\hline 8 & 0.69 & 0.55 & nd & 3.2 & & 1.4 \\
\hline 9 & 0.50 & 0.53 & nd & 5.7 & & 1.4 \\
\hline 10 & 0.67 & 0.55 & nd & 3.5 & & 1.4 \\
\hline 14 & 0.51 & 0.53 & nd & 2.0 & & 1.2 \\
\hline 21 & 0.47 & 1.77 & nd & 7.1 & & 2.5 \\
\hline 25 & 0.47 & 2.70 & nd & 12.2 & & 3.7 \\
\hline 32 & 0.45 & 7.71 & 0.99 & 36.8 & & 10.2 \\
\hline Days, Expt 3 & F ppm & $\mathrm{Cl} \mathrm{ppm}$ & Br ppm & $\mathrm{NO}_{3} \mathrm{ppm}$ & & $\mathrm{SO}_{4} \mathrm{ppm}$ \\
\hline 1 & 0.41 & 0.63 & nd & 1.1 & & 1.1 \\
\hline 2 & 0.36 & 0.41 & nd & 2.9 & & 1.1 \\
\hline 4 & 0.41 & 0.45 & nd & 2.7 & & 1.0 \\
\hline 5 & 0.54 & 0.34 & nd & 3.9 & & 1.3 \\
\hline 7 & 0.49 & 0.51 & nd & 4.0 & & 1.3 \\
\hline 8 & \begin{tabular}{|l|}
0.69 \\
\end{tabular} & 0.49 & nd & 2.4 & & 1.4 \\
\hline 10 & 0.74 & 0.46 & nd & 3.2 & & 1.3 \\
\hline 21 & 0.52 & 0.77 & nd & 5.3 & - & 2.0 \\
\hline 25 & 0.41 & 0.74 & nd & 6.0 & & 2.3 \\
\hline 32 & 0.38 & 1.28 & 0.33 & 10.5 & & 3.4 \\
\hline
\end{tabular}




\subsection{DATA INTERPRETATION}

The solution analyses presented in table 2 can be interpreted at several levels. In the following discussion two approaches are followed: first, empirical relationships in the solution data are discussed. The insights gained from these discussions are largely based on the ratios of different ions and serve to generate a qualitative model of the system behavior. The second approach taken involves "reaction path" calculations based on equilibrium thermodynamics (and a limited amount of rate data) to predict the behavior of idealized model systems at times corresponding to various stages of the experiment. These predictions are then compared to the experimentally determined solution chemistries in order to evaluate the success of the model, or elucidate mechanisms not considered in the initial model.

\subsection{Empirical Observations}

Results illustrated in the concentration-time plots (figures 6 and 7) reflect a combination of influences. For most of the elements the increased concentration later in the test (experiments 2 and 3) probably reflects the continued evaporation of the fluid. In fact, during the experiment significant decreases in water level (other than those arising from sampling) were noted. Table 3 contains concentration factors for the principal ions in both experiments. Two columns are listed for experiment 2, the first reflecting the full (and rather extreme) degree of evaporation at the end of the experiment and the second entry reflects a degree of evaporation (attained after 25 days) that is comparable to that experienced by experiment 3 during the full 32 days. Differences in evaporation rates are thought to reflect differences in the delivery rate of air bubbles to the two experiments.

\section{Table 3. Evaporation Ratios for Experiments 2 and 3}

\begin{tabular}{||l|l|l|l||}
\hline & Experiment 2 & Experiment 2 & Experiment 3 \\
\hline Element & 32 Days/3Days & 25 Days/3 Days & 32 Days/2 days \\
\hline $\mathrm{Na}$ & 5.5 & 2.9 & 2.8 \\
\hline $\mathrm{Ca}$ & 7.2 & 3.4 & 3.0 \\
\hline $\mathrm{Mg}$ & 2.9 & 1.7 & 2.1 \\
\hline $\mathrm{U}$ & $36^{*}$ & 10.8 & 11 \\
\hline $\mathrm{Cl}$ & $21(14)$ & 5.2 & 3.1 \\
\hline $\mathrm{NO}_{3}$ & 14 & 3.5 & 3.6 \\
\hline $\mathrm{SO}_{4}$ & 8 & 2.6 & 3.1 \\
\hline
\end{tabular}

( ) The day 8 chloride value appears more representative of the early behavior of the experiment.

* The early uranium signal is noisy so the day 1-3 average was used to compute baseline concentrations. 
For moderate degrees of evaporation the clearest picture of system evolution is presented by experiment 3 (though with somewhat more noise these trends are supported by experiment 2 , third column, table 2). For most of the ions an evaporation ratio of $\approx 3$ is suggested. Exceptions are magnesium (low), nitrate (high) and $\mathrm{U}$ (high). The $\mathrm{Mg}$ deficit can be ascribed to either ion exchange properties (on either clays or carbonates), or to the precipitation of a number of sparingly soluble hydroxide-carbonate salts. The source of the slight excess in nitrate can probably be attributed to the slow breakdown of natural organic material. The two uranium values (10.8 and 11) are close enough to suggest the uranium wire in experiment 3 had no influence the overall aqueous chemistry of that system (consistent with the low specific surface area of the wire). However, to explain the generally higher $U$ evaporation will require more detailed modeling of the system.

The first column of Experiment 1 (Table 3) suggests that as evaporation progresses additional processes come into play. Evaporation ratios for all the cations now lag significantly behind those for the anions and there is also a significant difference between the behavior of chloride or nitrate, and that of sulfate. The relative behavior of cations and anions can be explained by the fact that cation exchange is readily possible in soils but anion exchange capacities are limited. It is likely that as evaporation progressed some cations were sorbed onto the clays.

Two variations on the cation exchange process are possible. In the first case the clay is assumed to fully saturated with $\mathrm{Na}$ and $\mathrm{Ca}$ prior to the start of the experiment. As evaporation progressed the amount of sorbed $\mathrm{Na}$ increases relative to $\mathrm{Ca}$ in order to satisfy the constraints imposed by mathematics of the ion exchange equilibria equations. This would alter the solution composition such that the apparent evaporation ratio for $\mathrm{Na}$ would be lower than for $\mathrm{Ca}$, which is in fact observed.

Alternatively, other ions such as $\mathrm{H}^{+}$might also participate in the exchange process. The $\mathrm{pH}$ drop associated with this process would complement that arising from other processes that may also have occurred as evaporation progressed; e.g., schoepite dissolution (to form uranyl carbonate complexes) or magnesium carbonate precipitation. Thus, for a variety of reasons, as the salinity increased a pH drop might expected. This was not observed; instead the $\mathrm{pH}$ remained relatively constant $(\approx 8.4)$ throughout the experiment. The likely explanation is that other dissolved components acted as buffers. A cursory examination of the cation:anion ratios Table 2 reveals a gross excess of cations $(+/-$ early $=9.3,+/$-late $=2.2)$. Given that these slurries were made using desert soil it is likely that bicarbonate is the missing anion. The levels of bicarbonate needed to achieve charge balance are about $50 \mathrm{ppm}$ initially and about $140 \mathrm{ppm}$ for the last sample (assuming uranium is present initially as $\mathrm{UO}_{2}\left(\mathrm{CO}_{3}\right)_{2}{ }^{2-}$ and at the end as $\left.\mathrm{UO}_{2}\left(\mathrm{CO}_{3}\right)_{3}{ }^{4-}\right)$. This modest amount of bicarbonate is sufficient to maintain the $\mathrm{pH}$.

Support for the bicarbonate acting as a buffer can be found in the observation that at the end of the experiment, calculated system carbonate only triples (or quadruples if one counts the carbonate associated with the $U$ ) while the other anions are concentrated by much larger factors. While acting as a buffer the bicarbonate would be converted to carbon dioxide and would subsequently be removed by the air stream being used to agitate the experiment. Thus, the apparent selective removal of bicarbonate supports the idea that this ion is providing the 
buffering that appears to be taking place as evaporation progresses.

\subsection{Modeling}

The preceding interpretation was largely empirical. To proceed further requires a quantitative tool able to handle the complex interactions that evidently took place during the experiment. To deal with such situations geochemists have developed computer codes such as EQ3/6 (Wolery and Daveler, 1992) which compute equilibrium assemblages (solid phases and liquid compositions) as reactants are added, or in this case subtracted, in a step-wise manner. Ion exchange reactions and the kinetic aspects of the problem are not readily treated by these codes, in large measure because the supporting databases are fragmentary. The code does allow clay solid solutions to form, however, and the compositional changes in clays roughly mimics ion exchange.

The particular model constructed for these experiments fixes the $\mathrm{CO}_{2}$ partial pressure at that of normal air $\left(10^{-3.5} \mathrm{~atm}\right)$. In the first step a water composition similar to the early experimental water was equilibrated with an schoepite $\mathrm{UO}_{2}(\mathrm{OH})_{2}$ and an excess of calcite. This equilibration had the effect of converting the uranium to the more thermodynamically favored phase assemblage of becquerelite $\left(\mathrm{CaO} \cdot\left(\mathrm{UO}_{3}\right)_{6} \cdot 11 \mathrm{H}_{2} \mathrm{O}\right)$ plus compreignacite $\left(\mathrm{K}_{2} \mathrm{O} \cdot\left(\mathrm{UO}_{3}\right)_{6} \cdot 11 \mathrm{H}_{2} \mathrm{O}\right)$. At the same time bicarbonate and $\mathrm{pH}$ levels in this water were fixed by the equilibration of calcite and the atmospheric $\mathrm{CO}_{2}$.

In the second step of the model this fluid was isolated from the solids with which it had equilibrated. Water was then removed in small increments until at the end 95 percent of the water had been removed. After each removal step the equilibrium state of the system (minerals present and coexisting solution compositions) was recomputed. Precipitation of well-crystallized $\mathrm{CaUO}_{4}$ was suppressed because it is unlikely that it could form in the short time of the experiment (Serne et al., 1996, found amorphous $\mathrm{CaUO}_{4}$ formed over weeks of interaction). In addition, calcite precipitation had to be suppressed in the calculations, else the calcium concentrations dropped to unreasonably low values. The suppression of calcite is justified because it is likely that the presence of $\mathrm{Mg}$ would seriously inhibit calcite precipitation, even at several times oversaturation (Stumm and Morgan, 1981).

Figure 8 compares the modeled solution compositions (lines) with concentrations measured during experiment \#2 and \#3 (symbols). In preparing this figure the experimental data were overlain assuming a linear relationship between reaction progress and time (e.g. in both cases the experiments started when no moles of water had been removed and were done when 53 out of a possible 55.85 moles of water had been removed). In general, modeled and experimental $\mathrm{Na}, \mathrm{K}$, and $\mathrm{Ca}$ concentrations agreed reasonably well. In contrast, predicted $\mathrm{Mg}$ (not shown) concentrations were not close to those observed experimentally. However, as mentioned earlier, $\mathrm{Mg}$ was probably involved in a variety of ion exchange mechanisms, or possibly phase precipitation events, that were not evaluated by the code. Thus, this disagreement in $\mathrm{Mg}$ concentrations is not a serious drawback. 


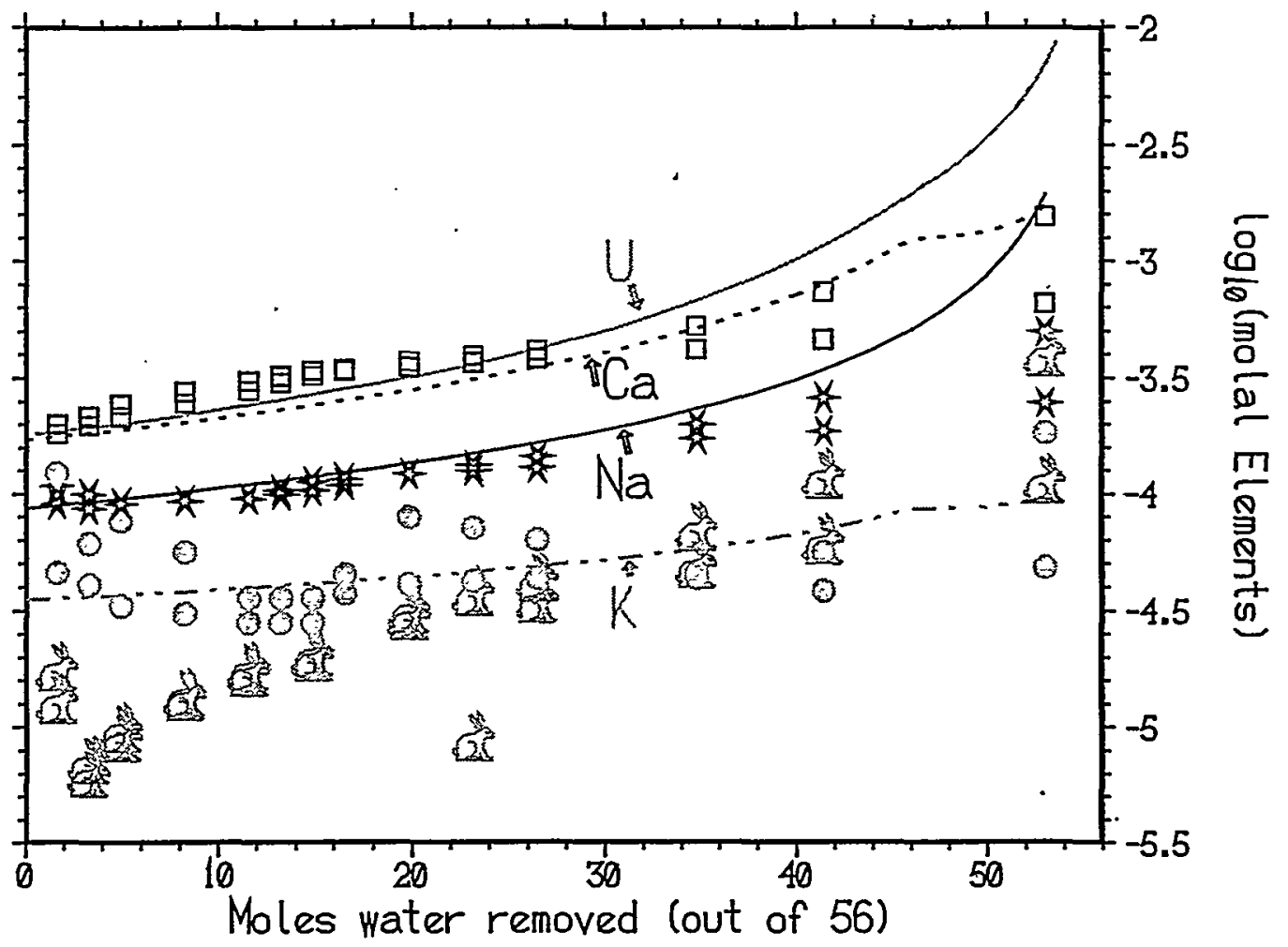

Figure 8. Calculated metals concentrations (lines) and concentrations determined in experiments 2 and 3 (symbols); squares $=\mathrm{Ca}$, stars $=\mathrm{Na}$, filled circles $=\mathrm{K}$, and rabbits $=\mathrm{U}$. The $\mathrm{Ca}, \mathrm{Na}$ and $\mathrm{K}$ experimental values are in reasonable agreement with the calculations, but the uranium experimental values are $\approx 1.5$ orders of magnitude lower than the predictions.

Of more direct concern is the ability of the EQ3/6 code to model uranium behavior, at least under the assumption of equilibrium. In general, a significant degree of undersaturation is evident for all the experimentally-determined uranium concentrations, even those representing a significant degree of evaporation. If schoepite is substituted for becquerelite as the solubility-limiting phase (perhaps more consistent with the X-ray diffraction analyses), the degree of undersaturation would have been even larger. The failure to achieve saturation suggests that there is a kinetic aspect of the problem that cannot be modeled by a purely equilibrium-based approach, at least on the time scale of the experiments. It is notable, however, that the equilibrium calculations are generally conservative here, tending to overestimate dissolved uranium concentrations.

Although the data on dissolution rates of uranium compounds are fragmentary (table 4), they are adequate to demonstrate that even though the uranium oxy-hydroxides were immersed in water for a month, one might still expect to see the degree of undersaturation observed in our experiments. The rates in table 4 represent the relative times required for complete dissolution of 
representative particles assuming that initial dissolution rates $\left(\mathrm{g} \cdot \mathrm{cm}^{-2} \cdot \mathrm{sec}^{-1}\right)$ hold throughout the process. We have assumed particle diameters from 0.001 to $0.01 \mathrm{~cm}(10$ to $100 \mu \mathrm{m})$, based on the spacing of cracks in figures 1-3 (crushing the samples in the mortar and pestle did little more than disaggregate the sled track material along existing cracks). The assumption of constant particle diameter generally leads to underestimation of the time for complete particle dissolution, since the surface areas of real particles usually decrease as they dissolve, slowing dissolution. However, the solution analyses for experimets \#2 and \#3 indicate that only about $0.3 \%$ of the initial uranium oxide dissolved in the course of the tests, so the end-stage system behavior is unimportant in the present analysis.

In compiling these rate data it became apparent that the partial pressure of carbon dioxide and solution $\mathrm{pH}$ were critical variables. The implication is that uranyl carbonate complexes play a significant role in the overall rate. Probably the most representative times are in the lower half of table 4 (i.e. 50 to $2.2 \times 10^{4}$ days). Assuming these rates, one calculates 4 hours to 66 days to dissolve $0.3 \%$ of the uranium in our experiments (the amount required to yield the observed experimental concentrations). Since the total experiment time was only 32 days, there is a strong possibility that our experiments were kinetically limited, and not solubility limited.

\section{Table 4. Calculated times to dissolve all Schoepite, $\mathrm{T}=25 \propto \mathrm{C}, 0.2 \mathrm{~atm} \mathrm{O}_{2}$}

\begin{tabular}{|l|c|c|}
\hline $\begin{array}{c}\text { Dissol. Rate }\left(\mathrm{g} \cdot \mathrm{cm}^{-2} \cdot \mathrm{sec}^{-1}\right) \text { and run } \\
\text { conditions }\end{array}$ & $\begin{array}{c}\text { Dissolution Time, average particle } \\
\text { diameter }=0.01 \mathrm{~cm}\end{array}$ & $\begin{array}{c}\text { Dissolution time, average particle } \\
\text { diameter }=0.001 \mathrm{~cm}\end{array}$ \\
\hline $\begin{array}{l}\mathrm{DR}=1.14 \cdot 10^{-9} \\
\mathrm{pH}=8.06, \mathrm{pCO}_{2}=0.011 \mathrm{~atm}^{(\mathrm{A})}\end{array}$ & 83 days & 8.3 days \\
\hline $\begin{array}{l}\mathrm{DR}=1.10 \cdot 10^{-9} \\
\mathrm{pH}=8.6, \mathrm{pCO}_{2}=0.02 \mathrm{~atm}{ }^{(\mathrm{B})}\end{array}$ & 86 days & 8.6 days \\
\hline $\begin{array}{l}\mathrm{DR}=1.88 \cdot 10^{-10} \\
\mathrm{pH}=9.0, \mathrm{pCO}_{2}=0.002 \mathrm{~atm}^{(\mathrm{B})}\end{array}$ & $5.0 \cdot 10^{2}$ days & 50 days \\
\hline $\begin{array}{l}\mathrm{DR}=4.25 \cdot 10^{-12} \\
\mathrm{pH}=9.82, \mathrm{pCO}_{2}=>0 \mathrm{~atm}^{(\mathrm{A})}\end{array}$ & $2.2 \cdot 10^{4}$ days & $2.2 \cdot 10^{3}$ days \\
\hline
\end{tabular}

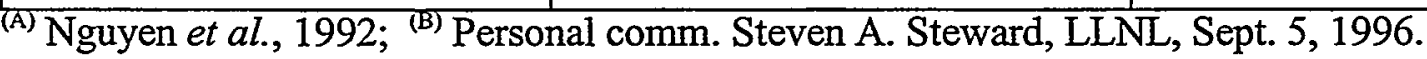

For comparison with our experimental results, the dissolution experiments performed by Casas et al. (1994) may be the most appropriate. Casas et al. determined schoepite dissolution rates for a single groundwater composition with a $\mathrm{pH}$ of 8.0 and containing about $20 \%$ of our initial calcium concentrations and four times our initial (calculated) bicarbonate concentrations; the $\mathrm{CO}_{2}$ fugacity was that of normal air, $\approx 10^{-3.5} \mathrm{~atm}$. Casas et al. found dissolution progressed by a two step process. The early rapid rate persisted for about 20 days and was thought to represent dissolution of a more reactive phases (possibly fine particles). Then, for the remainder of their test (583 days), the rate slowed by a factor of 16. It is thought that this later rate reflects dissolution of schoepite with grain sizes in the 10 to $100 \mu \mathrm{m}$ diameter range. We see no 
indication of an early rise in our dissolution data so it is likely that the rates on the later (coarser grained material) data are more appropriate. The particle sizes in our samples seem very similar to those used by Casas et al. (based on a comparison of SEM photographs), so we make no correction for specific surface area. Correcting for differences in sample weight, the Casas et al. rate data suggests that in 32 days about $2.1 \times 10^{-3}$ grams of uranium should have dissolved. A three fold concentration of the initial $500 \mathrm{ml}$ of fluid (due to evaporation) results in predicted final concentrations of $12.5 \mathrm{ppm} \mathrm{U}$ (experiment 3) and a 14 fold concentration results in a 58 ppm U concentration (experiment 2). Actual final concentrations in our experiments were 90 and $25 \mathrm{ppm} U$ for experiments 2 and 3 , respectively. Considering all of the uncertainties in the analysis it is surprising that there is only a factor of $\approx 2$ difference between calculation and experiment. This discrepancy could be readily accommodated by differences in surface areas between the two samples (as illustrated by table 4), or by the fact that the natural material used by Casas, et al., 1994 was more crystalline than the relatively young material derived from the sled track. Using twice the rate supplied by Casas et al. (1994), and assuming an absence of evaporation, one calculates 290 days for the system to reach becquerelite saturation (about $10^{-3.5}$ molar U; figure 1). Once again, this calculated time is significantly longer than that allotted for the experimental part of this program (32 days). Unfortunately, these rate data were not available when the experiment was planned in early 1993.

In short, the literature strongly supports the possibility that the $U$ concentrations in our experiments are the combined result of evaporative concentration and the continuous dissolution of the uranium source material. No evidence suggests that the uranium had equilibrated with any phase. As a consequence it is not surprising that the EQ3/6 modeling of the system failed to produce an exact match. The computational models do, however, illustrate why saturation is not achieved even with a 14 fold increase in concentration due to evaporation. As the ionic strength rises it is noted that the solubility of the source phase also increases. Thus, although the highest data point on the right side of Fig 10 approaches a value that would have achieved saturation early in the experiment, the solubility of the becquerelite source material under those conditions has also risen. In large measure this change reflects the decrease in activity coefficients computed for the divalent and tetravalent uranyl carbonate complexes as the overall ionic strength increases.

\subsection{SUMMARY}

Experimental studies and chemical analyses were used to gain insight about the behavior of metallic uranium in near-surface settings, such as the Sandia Sled Track and the GCD site at NTS. This work demonstrates that even in arid environments the buried metal will quickly alter to hydrous hexavalent uranium oxides that principally resemble the mineral schoepite. If other lower valent compounds are present they are restricted to the surfaces of residual metallic granules and have little effect on the mobility of uranium in theses environments. There is circumstantial evidence in the chemical analyses that some of the schoepite may have altered to Ca-uranates such as becquerelite. Other experimental studies (Serne et al., 1996; Sandino and Grambow, 1994) report Ca-uranates forming over days to weeks, and thermodynamic modeling and the general literature on uranium ore deposits suggest the Ca-uranates are ultimately more 
stable than schoepite in most near-surface environments.

To quantify the mobility of uranium in wetted desert soils, a pair of month-long uranium oxidesoil slurry experiments were carried out. At various times fluid samples were extracted for analysis. During the experiments a portion of the water evaporated in a manner that would mimic the drying of soil after a rainy season. At an empirical level these analyses revealed that $\sim 10$ to $\sim 100$ ppm uranium could be mobilized in the pore waters of freshly wetted soils.

Two types of models were used to help interpret the experimental results. The computer code EQ3/6 uses equilibrium thermodynamics to compute stable phases assemblages as reactions progress (while the code is capable of modeling kinetic dissolution, it was not used in that capacity for the present study). In this case the principal reactions modeled were the simultaneous subtraction of water from the system (evaporation) and the re-equilibration of the new fluid with the solids present, notably the uranium mineral becquerelite. This modeling demonstrated that a number of minerals such as calcite and dolomite probably had not precipitated during the course of our experiments even though they had achieved significant degrees of supersaturation. It also demonstrated that the uranium levels remained below saturation during the entire course of the experiment.

The second modeling effort involved simple kinetic calculations of schoepite dissolution; we wanted to know if our experimental solutions could remain undersaturated for such a prolonged period of time. If the kinetic data suggested that saturation should have been achieved, it would imply that we had failed to identify the major mechanism controlling uranium mobility in such systems. However, there was reasonable agreement between the predictions based on the literature and the laboratory results, given the uncertainty in effective particle sizes. Thus, it was concluded that we should not have expected equilibration in the one month time allotted for the experiments. Lastly we can infer that equilibrium (non-kinetic) EQ3/6 calculations are more likely to represent reality when used to model uranium-soil-water interactions that take place over periods of years instead of weeks.

\subsection{CONCLUSIONS}

The main objective of this study was to evaluate uranium transport from a metallic source in a near surface environment such as the GCD site in Nevada. A significant finding is that the metallic phase did not impose reducing conditions on the near-field chemical environment, possibly because the high porosity of the soil allowed rapid air influx. Hence, uranium solubility was controlled by hexavalent solids such as schoepite or becquerelite. Depending on the overall chemistry, tens or hundreds of ppm uranium may be found in pore waters. This uranium may subsequently precipitate on the surfaces of other mineral grains as the soil finally dries.

A secondary objective of this study was to test the usefulness of various computational tools in modeling (and predicting) uranium mobility. This effort met with a qualified success. Reaction path modeling with EQ3/6 in non-kinetic mode seemed to have the potential for predicting uranium concentration in solution, given the initial state of the system. This assessment proved 
to be overly optimistic, because the short term dissolution was kinetically limited. Of note were the ion exchange properties of the soil and a lack of equilibrium in the carbonate and uranium mineral systems. However, with the EQ3/6 results serving as a baseline, these complicating factors were readily identified and compensated. Thus, in the end an overall picture evolved that incorporated semiquantitative assessments of both equilibrium and kinetic aspects of the problem. With this level of understanding it is apparent that EQ3/6 predictions may be used to provide forecasts of system behavior for times that cannot be readily addressed experimentally.

\subsection{REFERENCES}

Casas, I.; Bruno, J.; Cera, E.; Finch, R.J. and Ewing, R.C. (1994) Kinetic and Thermodynamic Studies of Uranium Minerals, Assessment of the Long-term Evolution of Spent Nuclear Fuel, SKB Technical Report 94-16, Svensk Karnbranslehantering, AB, Box 5864 S-102 40 Stockholm, SWEDEN, $73 \mathrm{pp}$.

Chu, M.S.Y. and Bernard, E. S. (1991) Waste Inventory and Preliminary Source Term Model for the Greater Confinement Disposal Site at the Nevada Test Site, SAND81-0170, Sandia National Laboratories, Albuquerque, NM, 87185, 41 pp.

Finch, R.J. and Ewing, R.C. (1992) The corrosion of uraninite under oxidizing conditions, Jour. Nucl. Mater. 190, 133-156.

Garrels, R.M. and Christ, C.L. (1965) Solutions, Minerals and Equilibria, Freeman, Cooper \& Company, pp 253-256 and pp 388-394.

JCPDS (1992) PC-PDF Installation and Reference Guide for the PDF-2 CD-ROM Retrieval/Display System, version 2.13, International Center for Diffraction Data 1992, 1601 Park Lane, Swarthmore PA 19081-2389 (Information@ICDD.PREPNET.COM), 117 pp.

Kimball, K. and Stockman, H.W. (1992) Operating Procedure. Dionex 2000 Ion Chromatography (GCD OP 92/2.1/IC), revision 1, Geochemistry Department 6118, Sandia National Laboratories, Albuquerque, NM, 87185, April 24, 1992, 10 pp.

Krauskopf, K.B. (1967) Introduction to Geochemistry, John Wiley \& Sons, p 67.

Krumhansl, J.L. (1992) Operating Procedure. Spectraspan 7 DCP (GCD OP/92/2.1/DCP), revision 1, Geochemistry Department 6118, Sandia National Laboratories, Albuquerque, NM, 87185, April 15, 1992, 17 pp.

Nguyen, S.N.; Weed, H.C.; Leider, H.R. and Stout, R.B. (1992) Dissolution kinetics of UO2. I. Flow-through tests on UO2.00 pellets and polycrystalline schoepite samples in oxygenated, carbonate/bicarbonate buffer solutions at 25 EC, in: C.G. Sombret (ed.) Scientific Basis for Nuclear Waste Management XV, Materials Res. Soc. Symp. 257, 339-344. 
Pearcy, E.C.; Prikryl, J.D.; Murphy, W.M. and Leslie, B.W. (1994) Alteration of uraninite from the Nopal-I deposit, Peña Blanca District, Chihuahua, Mexico, compared to degradation of spent nuclear fuel in the proposed United States high-level nuclear waste repository at Yucca Mountain, Nevada, Applied Geochemistry 9, 713-732.

Recard, R.P. (1995) An Introduction to the Mechanics of Performance Assessment Using Examples of Calculations Done for the Waste Isolation Pilot Plant Between 1990 and 1992, SAND93-1378, Sandia National Laboratories, Albuquerque, NM . .

Sandino, M.C.A. and Grambow, B. (1994) Solubility equilibria in the U(VI)-Ca-K-Cl- $\mathrm{H}_{2} \mathrm{O}$ system: transformation of schoepite into becquerelite and compreignacite, Radiochimica Acta $66 / 67,37-43$.

Serne, R.J.; Rai, D.; Martin, P.F.; Felmy, A.R.; Rao, L. and Ueta, S. (1996) Leachability of Nd, $\mathrm{U}, \mathrm{Th}$, and $\mathrm{Sr}$ from cements in a $\mathrm{CO}_{2}$ free atmosphere, in: W.M. Murphy and D.A. Knecht (eds.) Scientific Basis for Nuclear Waste Management XIX, Mater. Res. Soc. Symp. Proc. 412, 459467.

SNLA (1993) Technical Area 3-5 RCRA Facility Investigation Work Plan, Chapter 14.0 Site 83: Sled Tracks, March 1993, Sandia National Laboratories, Environmental Restoration Dept., Albuquerque, NM 87185.

Sowder, A.G.; Clark, S.B. and Fjeld, R.A. (1996) The effect of silica and phosphate on the transformation of schoepite to becquerelite and other uranyl phases, Radiochimica Acta 74, 4549.

Stumm, W. and Morgan, J.J. (1981) Aquatic Chemistry, John Wiley and Sons, p. 316-317.

Wolery T.J. (1992) EQ3NR, a Computer Program for Geochemical Aqueous SpeciationSolubility Calculations: Theoretical Manual, User's Guide, and Related Documentation(Version 7.0) UCRL-MA-1 10662 PT III, Lawrence Livermore National Laboratory, Livermore, CA,

Wolery T.J. and Daveler S.A. (1992) EQ6, a Computer Program for Reaction Path Modeling of Aqueous Geochemical Systems: Theoretical Manual, User's Guide, and Related Documentation (Version 7.0) UCRL-MA-110662 PT IV, Lawrence Livermore National Laboratory, Livermore, $\mathrm{CA}, 337 \mathrm{pp}$. 


\section{Distribution:}

6 U.S. Department of Energy Waste Management Division Attn: Angela Colarusso, Nevada Operations Office P.O. Box 98518

N. Las Vegas, NV 89193-8518

6 Stu Rawlinson

Bechtel Nevada

MS-NLV 081

2621 Losee Road

N. Las Vegas NV 89030-4134

\section{Internal Distribution}

24 MS1345 J. R. Cochran, 6114

MS1345 P. A. Davis, 6114

5 MS1399 H. W. Stockman, 6118

MS0701 L. E. Shephard, 6100

MS0750 H. L. Anderson, 6118

5 MS0750 P. V. Brady, 6118

5 MS0750 J. L. Krumhansl, 6118

3 MS0750 H. R. Westrich, 6118

MS0750 P. Zhang, 6118

MS0612 Review \& Approval Desk, 4912

For Doe/OSTI

2 MS0899 Technical Library, 4916

MS9018 Central Technical files, 8940-2 